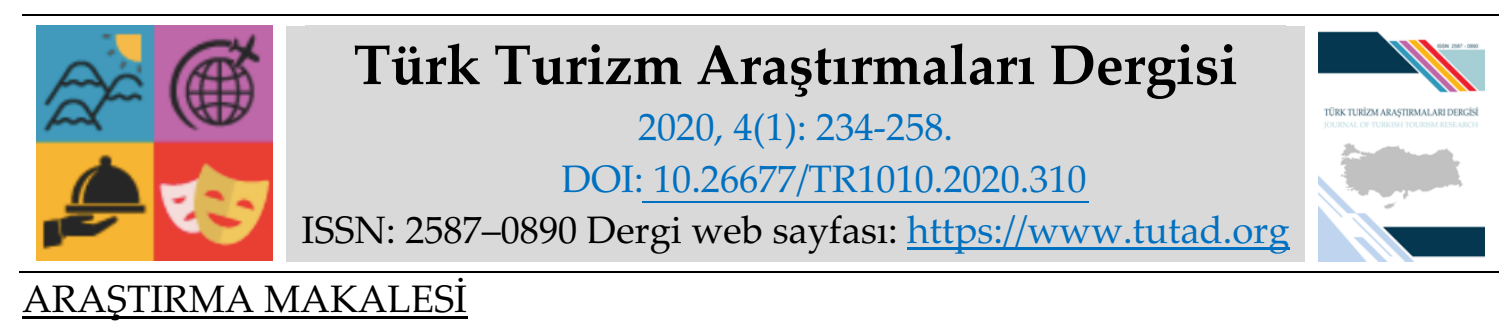

\title{
Destinasyonda Markalaşma Yolunda Şanlıurfa İçin Bir Model Önerisi*
}

Arş. Gör. Dr. Emrah YAŞARSOY, Kastamonu Üniversitesi, Turizm Fakültesi, Kastamonu, eposta: eyasarsoy@kastamonu.edu.tr

ORCID: https://orcid.org/0000-0002-9541-6601

Prof. Dr. Kutay OKTAY, Kastamonu Üniversitesi, Turizm Fakültesi, Kastamonu, e-posta: koktay@kastamonu.edu.tr

ORCID: https://orcid.org/0000-0003-0552-0913

Öz

Günümüz çetin rekabet koşullarında, destinasyonlar turizm pastasından daha fazla pay alabilmek için farklılaşma yolunda önemli adımlar atmaktadır. Bu noktada, yapılabilecek en önemli atılımlardan biri de markalaşmadır. Şanlıurfa, özellikle inanç turizmi, kültür turizmi ve gastronomi turizmi türlerine ev sahipliği yapacak potansiyele sahip bir şehirdir. Ancak mevcut imkânlar, Şanlıurfa'nın bir turizm kenti olarak kabul görmesi için etkin kullanılmamaktadır. Araştırmanın amacı, Şanlıurfa İlinin destinasyonda markalaşabilmesi için turizm potansiyelini belirlemek, mevcut turistik imajını ölçmek, yerli ziyaretçilerin Şanlıurfa'ya yönelik algılarını tespit etmek ve bunlara bağlı olarak bir model önerisi sunmaktır. Araştırmada nicel yöntem ve betimsel araştırma modeli kullanılmıştır. Araştırmada anket tekniğinden yararlanılarak araştırma örnekleminden veri elde edilmiştir. Elde edilen veriler, sosyal bilimlerde sık kullanılan istatistiksel bir paket programı yardımıyla çözümlenmiştir. Bu kapsamda, sıklık analizi, faktör ve güvenirlik analizi, korelasyon analizi, bağımsız örneklem t-testi, ANOVA testi ve KruskalWallis-H testi uygulanmıştır. Araştırmanın sonucunda, marka kent algısının yaşa, cinsiyete, eğitim durumuna ve aylık gelire göre farklılık göstermediği; Algılanan Kalite, Algılanan Değer, Destinasyon İmajı, Memnuniyet ve Marka Kent ölçeklerinde yer alan ifadelere verilen cevapların ortalamalarının yüksek olduğu belirlenmiştir. Son olarak, Şanlıurfa'nın destinasyonda markalaşması açısından fayda sağlayabilecek bir model önerisi ortaya konmuştur.

* Bu araştırma, Kastamonu Üniversitesi Sosyal Bilimler Enstitüsünde tamamlanan doktora tezinden türetilmiştir.

Anahtar Kelimeler: Turizm, Markalaşma, Destinasyon Markalaşması, Şanlıurfa.

Makale Gönderme Tarihi: 12.09.2019

Makale Kabul Tarihi: 07.01.2020

Önerilen Atıf:

Yaşarsoy, E. ve Oktay, K. (2020). Destinasyonda Markalaşma Yolunda Şanlıurfa İçin Bir Model Önerisi, Türk Turizm Araştırmaları Dergisi, 4(1): 234-258.

(C) 2020 Türk Turizm Araştırmaları Dergisi. 


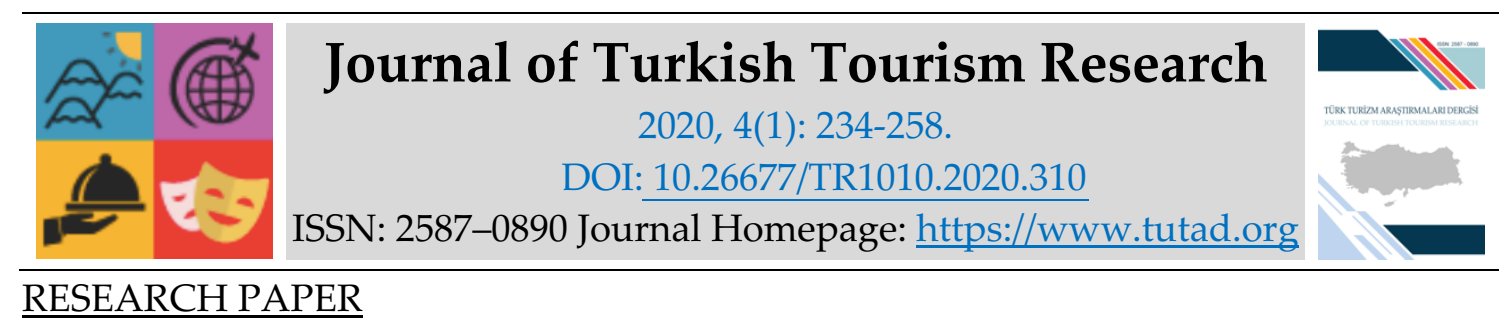

\title{
A Model Proposal for Şanlıurfa Towards Destination Branding
}

Dr. Emrah YAŞARSOY, Kastamonu University, Faculty of Tourism, Kastamonu, e-mail: eyasarsoy@kastamonu.edu.tr ORCID: https://orcid.org/0000-0002-9541-6601

Prof. Dr. Kutay OKTAY, Kastamonu University, Faculty of Tourism, Kastamonu, e-mail: koktay@kastamonu.edu.tr ORCID: https://orcid.org/0000-0003-0552-0913

\begin{abstract}
In today's challenging conditions of competition, destinations take important steps towards differentiation in order to get more share of the cake regarding tourism. At this point, branding is one of the most important breakthroughs. Şanliurfa is a city that has the potential to host especially faith tourism, cultural tourism and gastronomy tourism. However, the existing facilities are not able to be used effectively for Şanlıurfa to be accepted as a tourist city. The purpose of the study is to determine the tourism potential of Şanlıurfa province in order to be able to become a brand in the destination, to measure the image of the current tourism, to determine the perceptions of local visitors for Şanliurfa and to suggest a model proposal depending on those points. In the research, quantitative method and descriptive research model were used. In the research, data were obtained from the research sample by using the survey technique. The data obtained were analyzed by using a statistical package program, which is frequently used in social sciences. Within this scope, frequency analysis, factor and reliability analysis, correlation analysis, independent sample t-test, ANOVA and Kruskal-Wallis-H tests were implemented. As a result of the research, it was determined that the perception of brand city does not differ according to age, gender, educational background and monthly income; the answers given to the expressions in Perceived Quality, Perceived Value, Destination Image, Satisfaction and Branded City scales were high. Finally, a model proposal that can benefit the branding of Şanliurfa as a destination was put forward.
\end{abstract}

Keywords: Tourism, Branding, Destination Branding, Şanlıurfa.

Received: 12.09 .2019

Accepted: 07.01.2020

Suggested Citation:

Yaşarsoy, E. and Oktay, K. (2020). A Model Proposal for Şanlıurfa Towards Destination Branding, Journal of Turkish Tourism Research, 4(1): 234-258.

(C) 2020 Türk Turizm Araştırmaları Dergisi. 


\section{Gíriş}

Turizmin geliştiği destinasyonlarda olumlu anlamda sosyal, kültürel ve ekonomik birçok etki ortaya çıkmaktadır. Öncelikle, turizm faaliyetinin gelişmeye başladığ yerlerde, sermaye sahiplerinin farklı ölçeklerde turizm tesisleri kurması ve bu sayede yöre halkının istihdam edilmesi bu duruma birer örnek olarak verilebilir. Böylece, insanların ekonomik anlamda refah düzeyi yükselmektedir. Diğer yandan, yöreye gelen ziyaretçiler kendi kültürlerini de gittikleri bölgeye taşımakta ve gidilen yerde yaşanan kültür alışverişi sonucunda bir mozaik ortaya çıkmaktadır. Turizmin hareketlenmesiyle, bölgedeki sosyal hayat da hem yerel halk için hem de ziyaretçiler için canlanmaktadır.

Bu araştırmanın çalışma sahası olan Şanlıurfa turizm alanında çok farklı ürünlere ve potansiyele sahip bir şehirdir. Tarihin yeniden yazılmasına ışık tutan Göbeklitepe; maneviyatın derin anlamlar bulduğu, Hz. İbrahim ve Nemrut'un kızı Zeliha'nın mekânı Halil-ür Rahman Gölü (Balıklıgöl) ve Aynzeliha Gölü (Anzılha Gölü); son derece büyüleyici ortamıyla Mevlid-i Halil (Dergâh) Camii ve Mağarası; M.S. 812-814 yılları arasında Abbasiler tarafından yapılan, Şanlıurfa'nın bir bütün olarak görülebileceği Urfa Kalesi; içerisinde Çile Mağarası ve Şifalı Kuyu'nun da bulunduğu Hz. Eyyûb Makamı; Edessa Krallığı ve Bizans Dönemlerine ait mozaiklerin de yer aldığı Haleplibahçe Mozaikleri; şehrin yöreselliğinin derinden hissedileceği, farklı türde Şanlıurfa'ya has ürünlerin satın alınabileceği Bakırcılar Çarşısı (Hüseyniye Çarşıları), Kazzaz Pazarı (Bedesten) ve Gümrük Hanı; 6. yüzyıla ait bir kilise kalıntısının üzerine 1861 yılında yapılan Reji Kilisesi (Aziz Petrus ve Aziz Paulus Kilisesi) ve tarihi sokakları, kaplıcası, kayak merkezi, harabeleri, antik kentleri Şanlıurfa'nın görülmesi gereken belli başlı yerleridir. Bunların da ötesinde, şehir son derece zengin ve yöresel mutfağ 1 ile de ön plana çıkmaktadır. Bu kadar farklı turistik ürüne sahipken, Şanlıurfa'nın turizmde beklenen sonuçlara ulaşmasında; eldeki mevcut turistik ürünlerin ortaya konması, bunun için stratejik planın hazırlanması, tüm paydaşların bu sürece dâhil edilmesi ve bu plan ve projelerin işin ehli kurum ve kişiler tarafından yürütülmesi büyük önem arz etmektedir. Anlatılanlar kapsamında, Şanlıurfa'nın turizmde bir marka şehir olabilmesi bu araştırmanın problemi olarak belirlenmiştir ve çözüm arayışına gidilmiştir.

Şanlıurfa özelinde, destinasyon markalaşmasına dönük bir model ortaya konması amacıyla yapılan bu araştırmada, konu ile ilgili yapılan akademik araştırmalar derinlemesine incelenmiş, buradan hareketle bir anket formu oluşturulmuş ve özgün bir model ortaya konması için bu anket formu Şanlıurfa'yı ziyaret eden yerli turistlere uygulanmıştır. Daha önce yapılmış destinasyon markalaşması ile ilgili araştırmalar incelendiğinde, destinasyon imajı, destinasyonda rekabetçilik, marka imajı, imaj bileşenleri, destinasyonda farklılaşma gibi konularının ön plana çıktığ1 saptanırken (Edwards vd., 2000; Cai, 2002; Ooi, 2004; Hankinson, 2005); Şanlıurfa ile ilgili turizm araştırmalarına bakıldığında ise destinasyonda markalaşma, gastronomi kültürü, şehrin turizm potansiyeli gibi konularının incelendiği tespit edilmiştir (Kuvvetli, 2014; Akbıyık, 2014; Çelik, 2017). Bu araştırma, içerdiği 5 farklı ölçek ve ortaya koyduğu model sebebiyle daha önce yapılan çalışmalardan farklılık göstermektedir. Bu sebeple, araştırmanın bugüne dek yapılan çalışmalardan farklı bir içerikte olduğu ve literatüre katkı sağlayacağı düşünülmektedir ve araştırma bulgularının, Şanlıurfa'da turizme önerilecek model aracılığıyla uygulamada yarar getireceği varsayılmaktadır.

\section{LITERATÜR TARAMASI}

Son yıllarda, markalaşmanın anlamı hemen her alanda olduğu gibi turizm açısından da önemli bir hal almıştır. Clifton'a (2003) göre markalaşma artık bir modern kavram haline gelmiştir ve 
ürün ve hizmetlerden şirketlere, kâr amacı gütmeyen kuruluşlara ve hatta ülkelere kadar birçok alanda uygulanabilir bir kavram olmuştur. Ancak, pazarlamayla ilgili literatüre göre ürün markalaşmasının ilkeleri doğrudan hizmet için uygulanmayabilmektedir. Çünkü, hizmeti üründen ayıran üç önemli fark vardır; bunlar soyutluk, üretim ve tüketimin birbirinden ayrılmazlığı ve dağıtım konusundaki tutarsızlık şeklindedir (Aaker, 1991; Knowles, 2001; Keller, 2003). Benzer bir biçimde, Ooi’ye (2004) göre de ürün ve hizmet markalaşması arasındaki benzerlikler vurgulanmıştır, ancak farklar göz ardı edilmiştir. Bu yüzden, destinasyonun hizmet alt yapısı, markalaşma açısından önemle göz önünde bulundurulması gereken noktalardan biridir (Buhalis, 2000). Bir destinasyon bütün olarak ele alındığında, oradaki tüm ürünlerin, hizmetlerin ve deneyimlerin bir toplamı olarak kabul edilmektedir (Buhalis, 2000). McIntyre (1993) destinasyonu şu şekilde tanımlamıştır; destinasyon, bir turistin ziyaret etmek için tercih ettiği veya bu hizmeti sağlayanların pazarlamak için seçtiği, çekim unsurlarının ve turizmle ilişkili etkinliklerin ve hizmetlerin sunulduğu yerdir. Destinasyon markalaşmasını ise araştırmacılar aşağıdaki şekillerde tanımlamışlardır:

- Destinasyon markalaşması, bir destinasyonu tanımlayan ve farklılaştıran isim, sembol, logo, marka işareti veya diğer grafiklerin oluşturulmasını destekleyen, destinasyonla benzersiz bir şekilde ilişkili, unutulmaz bir seyahat deneyimi beklentisini taşıyan, ziyaretçiyle destinasyon arasındaki duygusal bağı pekiştirmek ve güçlendirmek için hizmet eden ve tüketici arama maliyetlerini ve algılanan riski düşüren bir takım pazarlama faaliyetleridir (Blain vd., 2005);

- Destinasyon markalaşması, varılacak yeri rekabet ortamında farklılaştıran ve destinasyonun benzersiz kimliğini ve kişiliğini vurgulayan, destinasyonun sahip olduğu tüm özellikleri bir kavram altında birleştiren bir süreçtir (Kaplanidou ve Vogt, 2003);

- Destinasyon markalaşması, tüm rakip destinasyonlardan farklı bir kimlik ve kişilik geliştirmek için kullanılan bir süreçtir (Gyimothy, 2000);

- Literatürdeki bu tanımlardan yola çıkarak, destinasyon markalaşmasını şu şekilde tanımlamak da mümkündür; destinasyon markalaşması, turistik bir yerin mevcut turizm potansiyelini kullanarak, rakiplerinden farklılaşması ve misafir memnuniyetini ön planda tutarak bu yönde öne çıkmayı gerektiren bir süreçtir. Logo, slogan, reklam müziği, renk gibi unsurları doğru stratejilerle işe koşan destinasyonlar markalaşma yolunda bir adım öteye rahatlıkla geçebilmektedir.

Yukarıda belirtilen tanımlardan da anlaşılacağı gibi destinasyon markalaşmasının, pazarlama literatüründen esinlendiği görülmektedir. Çünkü markalaşma kavramı başarılı bir şekilde hem somut hem de soyut öğelere kadar genişletilebilmektedir (Aaker, 1991; Murphy, 1998; Ward, Light ve Goldstein, 1999; Clifton, 2003). Ayrıca, destinasyon markalaşması ile ilgili yapılan tanımlardan hareketle, turistlerin destinasyonu bir ürün olarak algıladıkları ve destinasyonun özelliklerini duygusal ve bilişsel süreçlerden geçirerek değerlendirdikleri anlaşılmaktadır. Bu nedenle, markalaşma tam olarak destinasyonun karar verme sürecinde yer almaktadır ve marka, destinasyon pazarlamasının önemli bir bileşenidir (Morgan vd., 2002). Destinasyon markalaşmasındaki önemli bileşen ise benzersiz bir kimliğe sahip olmaktır. Benzersiz bir destinasyon kimliği oluşturmak için literatürde işlevsel, sembolik ve deneyimsel markalaşmanın kombinasyonunu anlatan araştırmalar mevcuttur (Laws, 1995; Laws, Scott ve Parfitt, 2002; Dredge ve Jenkins, 2003; Williams vd., 2004). Bu açıdan bakıldığında, bir destinasyonu markalama karışık bir süreçtir (Boo, 2006). Murphy ve arkadaşları (2000) belirli bir şekilde imal edilen bir ürünün aksine bir turizm destinasyonunu, ziyaret edilen alanın toplam deneyimini oluşturmak için bir araya gelen bireysel ürün ve deneyim fırsatlarının bir karışımı olarak değerlendirmişlerdir. 
Literatürde konuyla ilgili daha önce yapılan araştırmalara bakıldığında, destinasyonda markalaşmanın farklı açılardan ele alındığı görülmektedir. Seyahat ve Turizm Araştırmaları Kuruluşu (TTRA) 1998 yılında gerçekleşen konferansında destinasyon markalaşması konusuna önemle değinilmiştir. Aynı yıl içerisinde, Amerikan Pazarlama Bilimi (AMS) turizm destinasyonlarının markalaşması konusundaki akademik araştırmalara özel bir oturumda yer vermiştir. Boo'ya göre (2006), akademik dergilerden elde edilen destinasyon markalaşması ile ilgili literatürün sınırlı kullanılabilirliği, destinasyon markalaşması araştırmalarının zor olduğu anlamına gelmektedir ve destinasyon markalaşması yönetimi uygulamalarının zenginleştirilmesi için daha çok araştırmaya ihtiyaç duyulmaktadır (Boo, 2006). Buradan hareketle, konu ile ilgili ile ilgili araştırmaların gerek yabancı gerekse yerli yazında gün geçtikçe arttı̆̆ı görülmektedir. Örneğin; Morgan ve arkadaşlarının (2002) yaptıkları bir araştırmaya göre Yeni Zelanda'nın marka değeri piramidi üç aşamadan oluşmaktadır. Bunlar; markanın ne olduğu (işlevsel yararlar); markanın ne yaptığı (duygusal ve kendi kendini ifade eden faydalar) ve markanın ne anlama geldiği şeklindedir. $\mathrm{Bu}$ araştırma, turistler için destinasyon markalaşmasının işlevsel, duygusal ve kendi kendini ifade eden yararlar noktalarının altını çizmektedir (Morgan vd., 2002). Jago'ya göre (2003) destinasyon markalaşması ile öncelikle o yörenin çıkarları gözetilmektedir ve güçlü bir marka oluşturmanın hem işletmelerin hem de tüketicinin yararına olacağı ifade edilmektedir (Jago vd., 2003). Morgan ve arkadaşlarının (2002) modeline göre ise, bir destinasyonun önemli özelliklerinin ve o yerin tüketiciler için ne anlama geldiğini anlamak için araştırmalar yapılarak öncelikli olarak tüketicinin çıkarı sürekli olarak gözetilmelidir. Böylece, bir destinasyonu ziyaret sonucunda turistler ve turistlerin o geziden elde ettikleri yarar arasındaki ilişkiyi belirlemek ve bu yönde çaba sarf etmek destinasyon markalaşmasının doğasına erişmek bakımından doğru bir yoldur (Boo, 2006). Anlatılanlar ışığında, destinasyonda markalaşmanın karışık ve zor bir süreç olduğu aşikârdır. Bunun ancak tüm paydaşların bir araya gelerek, ortak bir amaç doğrultusunda bir yol haritası çıkararak uygulamaya koymalarıyla olabileceği düşünülmektedir. Ayrıca, bir destinasyonun markalaşması doğrultusunda belirlenecek logo, slogan, reklam müziği, renk gibi faktörlere doğru bir şekilde karar verilmesi, süreci daha kısa hale getirecektir. Markalaşma sürecinde, bir destinasyonda hizmet veren kesimin orada yaşayan halk olduğu düşünüldügüünde, yöreyi ziyaret edecek bireylerin olduğu kadar, yerel halkın da çıarlarının ön planda tutulması büyük önem arz etmektedir.

\section{YÖNTEM}

\section{Araştırmanın Amacı ve Önemi}

$\mathrm{Bu}$ araştırmanın amacı, Şanlıurfa İlinin destinasyonda markalaşabilmesi için turizm potansiyelini belirlemek, mevcut turistik imajını ölçmek, yerli ziyaretçilerin Şanlıurfa'ya yönelik algılarını tespit etmek ve buna yönelik bir model önerisi sunmaktır. Şanlıurfa'nın turizmde layık olduğu yere gelebilmesi bakımından somut bir yol haritası ortaya çıkarılması, model önerisi oluşturulması ve turizminin gelişimi için paydaşların birlikte hareket etmesine katkı sağlanmasına yönelik önerilerin geliştirilmesi bu araştırmanın temelini oluşturmaktadır.

Bu araştırma, daha önce Şanlıurfa turizmi ile ilgili yapılan bilimsel araştırmalardan farklı olarak, önerdiği model sebebiyle önem arz etmektedir. Bu açıdan bakıldığında, literatüre katkı sunacağı düşünülmektedir. Ayrıca, araştırma Şanlıurfa'nın sosyal, kültürel ve turistik değerlerinin şehrin turizmine tam anlamıla kazandırılması ve bunun kente sosyal, ekonomik ve kültürel açıdan değer katması bakımından önemlidir. 


\section{Araştırmanın Sınırlılıkları}

Her araştırmada olduğu gibi bu araştırmada da bazı sınırlılıklar bulunmaktadır. Bunları aşağıdaki şekilde belirtmek mümkündür:

- Destinasyon markalaşması konusu turizm alanında hatırı sayılı turistik ürünlere ve de değerlere sahip olan birçok yer için geçerli olabilir. Lâkin, bu araştırmada yalnızca Şanlıurfa'nın destinasyonda markalaşması üzerine odaklanılmıştır.

- Araştırma, Şanlıurfa'yı ziyaret eden ve il merkezinde bulunan yerli misafirler ile sinirlidir.

- Araştırmaya yalnızca Türkçe konuşan ve 18 yaş üzerindeki bireyler dâhil edilmiştir.

- Araştırma, literatür taraması sonucu erişilen kaynaklar (kitap, rapor, bildiri, makale ve tez gibi), konu ile alakalı güncel yayınlar, görsel veri toplama ve internet erişimi ile sinırlıdır.

\section{Araştırmanın Yöntemi ve Veri Toplama Aracı}

Bu araştırma nicel yöntemli bir araştırmadır. Nicel yöntem, olgu ve de olayları nesnelleştirerek; bunları gözlemlenebilir, ölçülebilir ve sayısal olarak açıklanabilir bir biçimde ortaya koyan bir araştırma türüdür (Arslan, 2012). Araştırmada, nicel bakımdan betimsel araştırma modeli kullanılmıştır. Betimsel araştırmalar, mevcut bir durumu elden geldiğince eksiksiz ve dikkatli bir biçimde tanımlayan araştırmalardır (Büyüköztürk vd., 2008). Bu tür araştırmalarda, araştırmaya konu olan olaylar, bireyler veya nesneler, kendi şartları içerisinde ve değiştirilmeden anlatılmaya çalışılır (Karasar, 1995; Yıldırım ve Şimşek, 2008; Pamukçu, 2017).

Araştırmada veri toplama aracı olarak anket tekniği kullanılmıştır. Öncelikle, konu ile ilgili daha önce kullanılmış ölçekler incelenmiştir. Ancak, araştırmada mevcut ölçeklerden de yararlanılarak, uzmanların görüşlerinin alınması sonrasında pilot araştırmayla birlikte yeni bir anket formu oluşturulmuştur (Deslandes, 2003; Özdemir, 2007;). Algılanan Kalite, Algılanan Değer, Destinasyon İmajı ve Memnuniyet Ölçekleri Derrick Donovan Deslandes'in "Destinasyonların Tüketici Algılarını Belirleme: Destinasyon Markalasma Sürecinde İlk Adım" başlıklı doktora tezinde kullandığı ölçeklerden uyarlanmıştır (Deslandes, 2003). Aynı zamanda, Deslandes'in araştırmasından uyarlanarak Gökçe Özdemir'in “Destinasyon Yönetimi ve Pazarlama Temelleri: İzmir İçin Bir Model Önerisi" başlıklı doktora tezinde Türkçe'ye çevrilen ölçeklerden de faydalanılmıştır (Özdemir, 2007). Marka Kent Ölçeği ise, araştırmacı tarafından alanyazın taraması da yapılarak sıfırdan geliştirilmiştir. Deslandes'in tezinden uyarlanarak hazırlanan ölçeklerde yer alan ifadelerde, alınan uzman görüşleri ve gerçekleştirilen pilot uygulama ile birlikte bazı değişiklikler ortaya çıkmıştır. Deslandes'in tezinde Algılanan Kalite Ölçeği'nde 5 ifade, Algılanan Değer Ölçeği'nde 9 ifade, Memnuniyet Ölçeği'nde 7 ve Destinasyon İmajı Ölçeği'nde 19 ifade yer alırken; bu araştırmada bu ifadeler sırasıyla 4, 6, 5 ve 10 şeklinde ortaya konmuştur. Bu ifadeler, tamamen katılıyorum $=5$, hiç katılmıyorum $=1$ şeklinde beşli Likert Tipi ölçeğe göre hazırlanmıştır.

\section{Araştırmanın Evreni ve Örneklemi}

$\mathrm{Bu}$ araştırmada, olasılığa dayalı örnekleme yöntemlerinden biri olan basit tesadüfi örnekleme yöntemi kullanılmıştır. Araştırmanın evreni, Şanlıurfa'yı 2018 yılının Nisan, Mayıs, Haziran ve Temmuz aylarında ziyaret eden ve il merkezinde konaklayan yerli turistlerdir.

Araştırmada hedeflenen en az örnek büyüklüğü Şanlıurfa için 385'tir. 400 kişinin 1.000 .000 kişilik bir ana kütleyi temsile yeterli olduğu (Krejcie ve Morgan, 1970) söylenebilir. Araştırmanın 
örneklemini Şanlıurfa İl Merkezi'nde yer alan Gümrükhanı ve Balıklıgöl'ü ziyaret eden bireyler ve iki adet 5 yıldızlı otelde konaklayan misafirler oluşturmaktadır. Şanlıurfa İl Merkezi'nde yer alan yukarıda bahsi geçen turistik mekânlarda ve şehrin en büyük iki otelinde konaklayan yerli ziyaretçilere anketler yüz yüze ve bırak-topla tekniğiyle uygulanmıştır.

Anket uygulaması tamamlandıktan sonra 476 ankete ulaşılmıştır. Eksik doldurulan 60 adet anket kapsam dişında tutulmuş ve böylece veriye sağlamaya elverişli 416 anket formu elde edilmiştir. Bahsi geçen anket Şanlıurfa İl Merkezine hitaben uygulanmıştır. O nedenle, \%5 önem düzeyinde ana kütleyi temsil eden söz konusu örnek büyüklükleri ile hata payı düşürülmüştür.

\section{Araştırmanın Hipotezleri}

$\mathrm{Bu}$ araştırmada, Şanlıurfa'nın destinasyonda markalaşması için bir model önerisi sunulması amaçlanmıştır. Bu noktada, Şanlıurfa'yı ziyaret eden yerli turistlerin bu konudaki düşünceleri analiz edilmiştir. Bunun yanında, katılımcıların demografik ve kişisel özelliklerine göre bu fikirlerin farklılık gösterip göstermediği, ölçekler arasında ne tür bir ilişkinin bulunduğu ve hangi ifadelerin daha önemli olduğu ele alınmıştır. Bu sebeple, bu amaçlar doğrultusunda bazı hipotezler geliştirilmiştir.

$\mathrm{H} 1, \mathrm{H} 2, \mathrm{H} 3$ ve $\mathrm{H} 4$ hipotezlerinin sınanması için karşılaştırma testleri uygulanmıştır. H1 hipotezinde, cinsiyete göre marka kent algısının farklılık gösterip göstermediği incelenmiştir. Cinsiyet iki nicel gruptan oluştuğu için burada bağımsız örneklem T Testi uygulanmıştır. H2, H3 ve $\mathrm{H} 4$ hipotezlerinde ise, marka kent algısının yaşa, aylık gelire ve eğitim durumuna göre farklılık gösterip göstermediği ortaya konmuştur. Yaş, aylık gelir ve eğitim durumu ikiden fazla nicel gruptan meydana geldiği için bu hipotezlerin test edilmesi için ise tek yönlü ANOVA testi ve Kruskal-Wallis-H testi uygulanmıştır.

Yüksek kalite veya üstün kalite, akademisyenler tarafından bir kalite avantajı olarak benimsenmektedir (İçöz, 2005). Kalite aynı zamanda, bir ürün veya hizmetin değeri olarak da isimlendirilmektedir (Şimşek ve Gürtuna, 2007). Kalite algısı bireyden bireye değişiklik göstermektedir, ancak genel anlamda bir destinasyonun insanların zihnindeki ortak kalite algısı o destinasyonun kalitesini belirlemektedir. Kalite, turistlerin destinasyon seçiminde önemli bir rol oynamaktadır (Özdemir, 2007). H5 hipotezinde, iki ayrı ölçek olan algılanan kalite ile algılanan değer arasındaki ilişki test edilmiştir.

İmaj oluştururken bazı önemli noktalar bulunmaktadır. Bunlardan bir kısmı ürünle ilgiliyken, diğer bir kısmı ise tüketicilerin gereksinimleri, kendi değerleri ve algıladıkları değerleri ve yaşam biçimleriyle ilgili olmaktadır (Odabaşı ve Oyman, 2006; Özdemir ve Karaca, 2009). H6 hipotezinde, algılanan değer ile destinasyon imajı arasındaki ilişki ölçülmüştür. "Destinasyon memnuniyeti, beklentiler ile karşılaştırılan destinasyon deneyimi arasındaki fark ile şekillenir. Beklentiler ile ürün performansı arasındaki fark da memnuniyet düzeylerini verir. Algılanan performans müşteri beklentilerini aştığı takdirde yüksek turist memnuniyeti; algılanan performansin müşteri beklentilerinin altında olduğunda ise düşük memnuniyet düzeyi oluşmaktadır. Bu durumda beklentileri karşılanmayan ancak seyahate çıkmak için maddi ve manevi birçok fedakârlıklarda bulunan turist seyahatinden memnun olmamış olarak döner. Ayrı ayrı incelendiğinde; destinasyon ürün ve hizmetler bütünü olduğu için, her ürün ve hizmetin memnuniyet düzeyi de farklı olmaktadır. Ancak burada önemli olan turistin bir bütün olarak genel anlamda seyahatinden memnun kalıp kalmadığıdır." (Özdemir ve Karaca, 2009). H7 hipotezinde ise destinasyon imajı ile memnuniyet arasındaki ilişki incelenmiştir. Son olarak, H8 ve alt hipotezlerinde ise, destinasyon markalaşmasında süreç unsurları olan belirtilen algılanan 
kalite, algılanan değer, memnuniyet ve destinasyon imajı (Deslandes, 2003) ile markalaşma çıktısı olarak sıfırdan geliştirilen marka kent ölçeği arasındaki ilişkiler sınanmıştır.

H1: Marka kent alg1Sı cinsiyete göre farklılık göstermektedir.

H2: Marka kent algısı yaşa göre farklılık göstermektedir.

H3: Marka kent algısı aylık gelire göre farklılık göstermektedir.

H4: Marka kent algısı eğitim durumuna göre farklılık göstermektedir.

H5: Algılanan kalite ile algılanan değer arasında istatistiksel bir ilişki vardır.

H6: Algılanan değer ile destinasyon imajı arasında istatistiksel bir ilişki vardır.

H7: Destinasyon imajı ile memnuniyet arasında istatistiksel bir ilişki vardır.

H8: Destinasyon markalaşma süreci ile marka kent arasında istatistiksel bir ilişki vardır.

H8a: Algılanan kalite ile kültürel açıdan marka kent arasında istatistiksel bir ilişki vardır.

H8b: Algılanan kalite ile stratejik açıdan marka kent arasında istatistiksel bir ilişki vardır.

H8c: Algılanan değer ile kültürel açıdan marka kent arasında istatistiksel bir ilişki vardır.

H8d: Algılanan değer ile stratejik açıdan marka kent arasında istatistiksel bir ilişki vardır.

H8e: Destinasyon imajı ile kültürel açıdan marka kent arasında istatistiksel bir ilişki vardır.

H8f: Destinasyon imajı ile stratejik açıdan marka kent arasında istatistiksel bir ilişki vardır.

H8g: Memnuniyet ile kültürel açıdan marka kent arasında istatistiksel bir ilişki vardır.

H8h: Memnuniyet ile stratejik açıdan marka kent arasında istatistiksel bir ilişki vardır.

\section{BULGULAR}

Araştırmanın bu kısmında, destinasyon markalaşma süreci kapsamında yer alan algılanan kalite, algılanan değer, memnuniyet ve imaj ölçeklerinden ve bunun bir sonucu olarak değerlendirilen marka kent ölçeğinden elde edilen bulgulara yer verilmiştir. Uygulanan anket sonucunda toplanan veriler istatistiki yöntemler kullanılarak analiz edilmiştir. Katılımcıların demografik özelliklerine yönelik frekans analizinin yanı sıra faktör ve güvenirlik analizleri yapılmıştır. Ardından, betimsel istatistik, korelasyon analizi, karşılaştırmalı testlerden bağımsız örneklem ttesti, ANOVA ve Kruskal-Wallis-H testleri uygulanmıştır.

\section{Katılımcıların Demografik Özelliklerine İlişkin Frekans Analizi}

Katılımclların demografik özellikleri şu şekilde özetlenebilir (Tablo 1): Katılımcıların \%55,0'i erkek iken \%41,9'unun kadın olduğu belirlenmiştir. Ankete katılan bireylerin \%31,3'ü 19-25 yaş grubuna ait kişilerden oluşmaktadır. 54 yaş ve üzeri katılımcıların sayısı ise \%7,2 olarak belirlenmiştir. Meslek gruplarına bakıldığında, katılımcılardan \%19,2'sinin öğrenci, \%13,2'sinin ise öğretmen olduğu ortaya çıkmıştır. Emekli olanların oranı ise \%5,3 olarak saptanmıştır. Katılımcıların \%21,4'ü aylık 1500 TL ve altı gelire sahip olduklarını belirtirken; \%12,4'ü 5501 TL ve üzeri gelire sahip olduklarını dile getirmişlerdir. Katılımcıların $\% 14,9^{\prime} \mathrm{u}$ ise aylık gelirlerini belirlemeye dönük soruyu yanıtsız bırakmışlardır. Katılımcların eğitim durumuna bakıldığında, $\% 42,1$ 'inin lisans düzeyinde eğitim aldıkları ortaya çıkmıştır. Katılımcıların \%14,7'sinin sürekli 
yaşadığ yer İstanbul olarak belirtilmiş iken yine \%8,7'sinin doğup büyüdüğü yerin de İstanbul olduğu belirlenmiştir.

Tablo 1. Katılımcıların Demografik Özelliklerine İlişkin Frekans Analizi

\begin{tabular}{|c|c|c|c|c|c|c|c|}
\hline & & $\mathrm{n}$ & $\%$ & & & $\mathrm{n}$ & $\%$ \\
\hline \multirow[t]{4}{*}{ Cinsiyet } & Kadın & 174 & 41,9 & \multirow[t]{10}{*}{$\begin{array}{c}\text { Eğitim } \\
\text { Durumunuz }\end{array}$} & $\begin{array}{l}\text { Okuma yazma } \\
\text { bilmiyorum }\end{array}$ & 1 & 0,2 \\
\hline & Erkek & 229 & 55,0 & & İlkokul & 9 & 2,2 \\
\hline & Yanitsiz & 13 & 3,1 & & Ortaokul & 20 & 4,8 \\
\hline & Toplam & 416 & 100,0 & & Lise & 94 & 22,6 \\
\hline \multirow[t]{9}{*}{ Yaş } & $\begin{array}{l}18 \text { yaş ve } \\
\text { altı }\end{array}$ & 16 & 3,8 & & Ön lisans & 51 & 12,3 \\
\hline & $19-25$ & 130 & 31,3 & & Lisans & 175 & 42,1 \\
\hline & $26-32$ & 119 & 28,6 & & Yüksek lisans & 42 & 10,1 \\
\hline & $33-39$ & 44 & 10,6 & & Doktora & 7 & 1,7 \\
\hline & $40-46$ & 35 & 8,4 & & Yanitsız & 17 & 4,1 \\
\hline & $47-53$ & 28 & 6,7 & & Toplam & 416 & 100,0 \\
\hline & $\begin{array}{l}54 \text { yaş ve } \\
\text { üzeri }\end{array}$ & 30 & 7,2 & \multirow[t]{7}{*}{$\begin{array}{c}\text { Sürekli } \\
\text { yaşadığınız yer }\end{array}$} & İstanbul & 61 & 14,7 \\
\hline & Yanitsiz & 14 & 3,4 & & Ankara & 32 & 7,7 \\
\hline & Toplam & 416 & 100,0 & & Kastamonu & 26 & 6,3 \\
\hline \multirow[t]{7}{*}{ Mesleğiniz } & Öğrenci & 80 & 19,2 & & Gaziantep & 25 & 6,0 \\
\hline & Öğretmen & 55 & 13,2 & & Konya & 23 & 5,5 \\
\hline & Emekli & 22 & 5,3 & & Diğer & 249 & 59,8 \\
\hline & Ev hanımı & 14 & 3,4 & & Toplam & 416 & 100,0 \\
\hline & Avukat & 12 & 2,9 & \multirow{11}{*}{$\begin{array}{c}\text { Doğup } \\
\text { büyüdüğünüz } \\
\text { yer }\end{array}$} & İstanbul & 36 & 8,7 \\
\hline & Diğer & 233 & 54,0 & & Ankara & 29 & 7,0 \\
\hline & Toplam & 416 & 100,0 & & Antalya & 22 & 5,3 \\
\hline \multirow[t]{8}{*}{$\begin{array}{c}\text { Aylık } \\
\text { Geliriniz }\end{array}$} & $\begin{array}{l}1500 \text { TL ve } \\
\text { altı }\end{array}$ & 89 & 21,4 & & Kastamonu & 22 & 5,3 \\
\hline & $\begin{array}{l}1501-2500 \\
\text { TL }\end{array}$ & 50 & 12,0 & & Gaziantep & 21 & 5,0 \\
\hline & $\begin{array}{l}2501-3500 \\
\text { TL }\end{array}$ & 63 & 15,1 & & Diğer & 286 & 68,7 \\
\hline & $\begin{array}{l}3501-4500 \\
\text { TL }\end{array}$ & 67 & 16,1 & & Toplam & 416 & 100,0 \\
\hline & $\begin{array}{l}4501-5500 \\
\text { TL }\end{array}$ & 41 & 9,9 & & & & \\
\hline & $\begin{array}{l}5501 \text { TL ve } \\
\text { üzeri }\end{array}$ & 44 & 10,6 & & & & \\
\hline & Yanitsız & 62 & 14,9 & & & & \\
\hline & Toplam & 416 & 100,0 & & & & \\
\hline
\end{tabular}

\section{Açıklayıcı Faktör Analizi ve Güvenirlik Analizi Sonuçları}

Araştırmada kullanılan 5 farklı ölçeğin, faktör analizine uyup uymadığını belirlemek amacıyla KMO ve Bartlett testleri uygulanmıştır. Algılanan Kalite, Algılanan Değer, Destinasyon İmajı, Memnuniyet ve Marka Kent ölçeklerinin KMO değerinin 0,500'den büyük olduğu ve Bartlett X2 testinin anlamlı bulunduğu saptanmıştır. Ölçeklerle ilgili KMO Değerlerine Tablo 2'de yer verilmiştir. Buradan hareketle, ölçeklerin faktör analizi için uygun olduğu sonucu çıkmıştır (Kalaycı, 2010) ve yapılan faktör analizlerinde, varimax döndürme yöntemi uygulanmıştır. 
Tablo 2. Bartlett Testi KMO Değerleri

\begin{tabular}{|l|c|}
\hline Ölçek & $\begin{array}{c}\text { KMO Örneklem Yeterlilik } \\
\text { Ölçüsü }\end{array}$ \\
\hline Algılanan Kalite &, 757 \\
\hline Algılanan Değer &, 876 \\
\hline Destinasyon İmajı &, 886 \\
\hline Memnuniyet &, 809 \\
\hline Marka Kent &, 769 \\
\hline
\end{tabular}

Cronbach alfa katsayısının 0-1 arasında değiştiği bilinmektedir. Değerlendirme kıstaslarına göre, bu sayı 0,00<0,40 arasında olduğunda ölçek güvenilir değili; 0,40<0,60 arasında olduğunda ölçek orta güvenilir; bu sayının 0,60<0,80 arasında olması güvenilir ve 0,80<1,00 olması ise yüksek güvenilir şeklinde ifade edilir (Tavşancıl, 2005). Tablo 3'te de görüldügü şekilde Algllanan Kalite, Alg̨lanan Değer ve Memnuniyet ölçeklerinin güvenirlik katsayılarının sırasıyla 0,832, 0,863 ve 0,838 olduğu ve bu durumda ölçeklerin güvenirliğinin çok yüksek olduğu anlaşılmaktadır. Tablo 3 'te belirtilen ölçeklerin her birinin tek boyut altında toplandığı ortaya çıkmıştır. İfadelerle ilgili aritmetik ortalamalara bakıldığında ise, Algılanan Kalite Ölçeği'nde "İyi kalitede restoranları vardır." ifadesi 3,81 ile; Algılanan Değer Ölçeği'nde "Bu seyahatin anıları bende uzun süre kalacaktır." ifadesi 4,08; Memnuniyet Ölçeği'nde ise "Bu seyahat güzel bir deneyimdi." ifadesi 4,06 ortalama ile en yüksek ortalamaya sahip olmuşlardır.

Tablo 3. Algılanan Kalite, Algılanan Değer ve Memnuniyet Ölçeği Faktör Analizi Sonuçları

\begin{tabular}{|c|c|c|c|c|c|}
\hline Ölçek/Boyut & Madde & $\begin{array}{l}\text { Faktör } \\
\text { Yükü }\end{array}$ & $\begin{array}{l}\text { Aritmetik } \\
\text { Ortalama }\end{array}$ & $\begin{array}{c}\text { Açıklanan } \\
\text { Varyans } \\
\text { Oranı }\end{array}$ & $\begin{array}{c}\text { Cronbach's } \\
\text { Alpha } \\
\text { Katsayısı }\end{array}$ \\
\hline \multirow{4}{*}{$\begin{array}{l}\text { Algılanan Kalite } \\
\text { Ölçeği }\end{array}$} & $\begin{array}{l}\text { Konaklama tesislerinin hizmet } \\
\text { kalitesi yüksektir. }\end{array}$ & 831 & 3,59 & \multirow[t]{4}{*}{66,526} & \multirow[t]{4}{*}{,832 } \\
\hline & $\begin{array}{l}\text { Şanlıurfa turizm noktasında bütün } \\
\text { olarak çok iyi kalitededir. }\end{array}$ & 830 & 3,51 & & \\
\hline & $\begin{array}{l}\text { Şanliurfa'da sağlanan hizmetin } \\
\text { kalitesine çok güvenirim. }\end{array}$ & 824 & 3,45 & & \\
\hline & İyi kalitede restoranları vardır. & 777 & 3,81 & & \\
\hline \multirow{6}{*}{$\begin{array}{l}\text { Algılanan Değer } \\
\text { Ölçeği }\end{array}$} & $\begin{array}{l}\text { Bu seyahatten gerçek anlamda keyif } \\
\text { aldım. }\end{array}$ & 848 & 4,00 & \multirow[t]{6}{*}{59,994} & \multirow[t]{6}{*}{863} \\
\hline & $\begin{array}{l}\text { Buraya gelme kararımla ilgili } \\
\text { kendimi iyi hissediyorum. }\end{array}$ & 844 & 4,05 & & \\
\hline & $\begin{array}{l}\text { Bu seyahatin anıları bende uzun } \\
\text { süre kalacaktır. }\end{array}$ & ,796 & 4,08 & & \\
\hline & Bu seyahat iyi bir değere sahiptir. & ,765 & 4,00 & & \\
\hline & $\begin{array}{l}\text { Bu seyahatin bana sosyal itibar } \\
\text { sağlayacağını düşünüyorum. }\end{array}$ & ,705 & 3,65 & & \\
\hline & $\begin{array}{l}\text { Burada dinlendirici zaman } \\
\text { geçirdim. }\end{array}$ & 672 & 3,89 & & \\
\hline \multirow{4}{*}{$\begin{array}{l}\text { Memnuniyet } \\
\text { Ölçeği }\end{array}$} & $\begin{array}{l}\text { Şanlıurfa'ya seyahat etmiş } \\
\text { olmaktan memnunum. }\end{array}$ & 858 & 4,05 & \multirow[t]{4}{*}{67,356} & \multirow[t]{4}{*}{838} \\
\hline & Bu seyahat beklediğim gibi oldu. &, 844 & 3,89 & & \\
\hline & $\begin{array}{l}\text { Tam olarak ihtiyacım olan bir } \\
\text { seyahat gerçekleştirdim. }\end{array}$ & 800 & 3,80 & & \\
\hline & Bu seyahat güzel bir deneyimdi. & ,778 & 4,06 & & \\
\hline
\end{tabular}


Tablo 4. Destinasyon İmajı ve Marka Kent Ölçeği Faktör Analizi Sonuçları

\begin{tabular}{|c|c|c|c|c|c|c|}
\hline Ölçek & Boyut & Madde & $\begin{array}{c}\text { Faktör } \\
\text { Yükü }\end{array}$ & $\begin{array}{l}\text { Aritmetik } \\
\text { Ortalama }\end{array}$ & $\begin{array}{c}\text { Açıklanan } \\
\text { Varyans } \\
\text { Oranı }\end{array}$ & $\begin{array}{c}\text { Cronbach's } \\
\text { Alpha }\end{array}$ \\
\hline \multirow{10}{*}{$\begin{array}{l}\text { Destinasyon } \\
\text { İmajı Ölçeği }\end{array}$} & \multirow[t]{7}{*}{ Çekicilikler } & Gece hayatı iyidir. & ,729 & 2,82 & \multirow[t]{7}{*}{41,747} & \multirow[t]{7}{*}{,833 } \\
\hline & & İklimi güzeldir. & ,722 & 3,49 & & \\
\hline & & $\begin{array}{l}\text { Buraya seyahat gerçek bir } \\
\text { maceradır. }\end{array}$ & ,709 & 3,67 & & \\
\hline & & Her şey farklı ve etkileyicidir. & ,703 & 3,75 & & \\
\hline & & $\begin{array}{l}\text { İlgi çekici pek çok mekân } \\
\text { mevcuttur. }\end{array}$ & 682 & 4,01 & & \\
\hline & & Güzel bir doğal manzarası var. & 637 & 3,90 & & \\
\hline & & $\begin{array}{l}\text { Yerel mimari tarzı kendine } \\
\text { özgüdür. }\end{array}$ &, 531 & 4,10 & & \\
\hline & \multirow[t]{3}{*}{ Özellikler } & Yerel halk misafirperverdir. & 749 & 4,28 & \multirow[t]{3}{*}{11,713} & \multirow[t]{3}{*}{, 543} \\
\hline & & $\begin{array}{l}\text { Yemekler damak tadıma } \\
\text { uygundur. }\end{array}$ & ,716 & 4,16 & & \\
\hline & & $\begin{array}{l}\text { Şanlıurfa ziyaret edilecek } \\
\text { güvenli bir yerdir. }\end{array}$ &, 593 & 4,01 & & \\
\hline \multirow[t]{10}{*}{$\begin{array}{l}\text { Marka Kent } \\
\text { Ölçeği }\end{array}$} & \multirow[t]{5}{*}{$\begin{array}{l}\text { Kültürel } \\
\text { Bakımdan } \\
\text { Marka Kent }\end{array}$} & $\begin{array}{l}\text { Kentin zengin kültürel mirasını } \\
\text { vurgulayan ulusal düzeyde } \\
\text { tanıtım ve pazarlaması } \\
\text { yapılmaktadır. }\end{array}$ & 842 & 3,18 & \multirow[t]{5}{*}{31,181} & \multirow[t]{5}{*}{825} \\
\hline & & $\begin{array}{l}\text { Kentin zengin kültürel mirasını } \\
\text { vurgulayan uluslararası } \\
\text { düzeyde tanıtım ve } \\
\text { pazarlaması yapılmaktadır. }\end{array}$ & 823 & 3,17 & & \\
\hline & & $\begin{array}{l}\text { Yerel halk, kültürel mirasın } \\
\text { değeri ve korunması } \\
\text { konusunda bilinçlidir. }\end{array}$ & 800 & 3,18 & & \\
\hline & & $\begin{array}{l}\text { Şehrin kültür turizmi } \\
\text { potansiyeli iyi } \\
\text { değerlendirilmektedir. }\end{array}$ & ,716 & 3,66 & & \\
\hline & & $\begin{array}{l}\text { Yöresel etkinlikler uluslararası } \\
\text { standartlara uygun biçimde } \\
\text { yapılmaktadır. }\end{array}$ & 638 & 3,49 & & \\
\hline & \multirow{5}{*}{$\begin{array}{c}\text { Stratejik } \\
\text { Bakımdan } \\
\text { Marka Kent }\end{array}$} & $\begin{array}{l}\text { Alternatif turizm faaliyetleri } \\
\text { çeşitlendirilmelidir. }\end{array}$ & ,766 & 4,11 & \multirow[t]{5}{*}{23,375} & \multirow[t]{5}{*}{ 676 } \\
\hline & & $\begin{array}{l}\text { Şehrin farklı paydaşlarının söz } \\
\text { sahibi olduğu bir turizm } \\
\text { stratejisi oluşturulmalıdır. }\end{array}$ & ,715 & 4,11 & & \\
\hline & & $\begin{array}{l}\text { Şehir turizmi potansiyelini } \\
\text { geliştirmeye yönelik plan ve } \\
\text { projelere ihtiyaç vardır. }\end{array}$ & ,676 & 4,09 & & \\
\hline & & $\begin{array}{l}\text { Şehrin yöresel yemekleri ön } \\
\text { plana çıkarılmaktadır. }\end{array}$ &, 577 & 4,13 & & \\
\hline & & $\begin{array}{l}\text { Kültürel ve sanatsal } \\
\text { gösterilerin düzenleneceği } \\
\text { tesisler ve mekânlar yeterli } \\
\text { değildir. }\end{array}$ &, 522 & 3,77 & & \\
\hline
\end{tabular}

Tablo 4'te Destinasyon İmajı ve Marka Kent ölçekleriyle ve bu ölçeklerin boyutlarıyla ilgili güvenirlik değerleri görülmektedir. Destinasyon İmajı Ölçeğinin güvenirlik katsayısının 0,835 olduğu; ölçek kapsamında Çekicilikler Boyutunun 0,833 ve Özellikler Boyutunun ise 0,543 olduğu belirlenmiştir. Bu noktada, Özellikler boyutunun güvenirliğinin 0,40 - 0,60 arasından olduğundan, orta güvenirlikte olduğu ortaya çıkmıştır. Marka Kent Ölçeğinin güvenirlik katsayısının ise 0,724 olduğu; ölçek kapsamında Kültürel Bakımdan Marka Kent Boyutunun 
0,825 ve Stratejik Bakımdan Marka Kent Boyutunun ise 0,676 olduğu belirlenmiştir. Bu noktada, Stratejik Bakımdan Marka Kent Boyutunun güvenirlik katsayısının 0,60 - 0,80 arasında olduğu; bu sonucun da boyutun güvenilir olduğunu ortaya koymuştur. Uygulanan faktör analizi sonucunda, Destinasyon İmajı Ölçeğinin, Çekicilikler ve Özellikler şeklinde; Marka Kent Ölçeğinin ise Kültürel Bakımdan Marka Kent ve Stratejik Bakımdan Marka Kent biçiminde iki alt boyutta toplandığı ortaya çıkmıştır. Destinasyon İmajı Ölçeği'nde, "Yerel halk misafirperverdir." ifadesi 4,28 ile; Marka Kent Ölçeği'nde ise "Şehrin yöresel yemekleri ön plana çıarılmaktadır." 4,13 ortalama ile en yüksek ortalamaya sahip ifadeler olmuşlardır.

\section{Karşılaştırma Testleri}

Bu araştırmada, Şanlıurfa'nın destinasyon olarak markalaşabilmesi adına genel geçer bir model önerisi geliştirmek için yapılandırılan ölçeklerin katılımcıların demografik özelliklerine göre istatistiksel olarak anlamlı farklılıklar gösterip göstermediğini incelemek için bağımsız gruplar t testi, tek yönlü ANOVA ve Kruskal-Wallis-H testleri kullanılmıştır. Bağımsız Gruplar T Testi, birbirinden bağımsız iki nicel grubun değişkenler bakımından karşılaştırılması için kullanılan testtir; Tek Yönlü ANOVA ise normal dağılım gösteren $\mathrm{k}(\mathrm{k} \geq 2)$ adet ana kütleden alınan, $\mathrm{k}$ adet bağımsız grup ortalaması arasındaki farklılığın belirlenmesinde kullanılan bir tekniktir. Tek Yönlü ANOVA testinin parametrik olmayanı ise Kruskal-Wallis-H testidir (Lorcu, 2015).

\section{Normallik Testi}

Çalışmada ortaya konan hipotezler için yapılacak olan karşılaştırma testlerinde, ihtiyaç duyulan varsayımlardan biri de verilerin normal dağılıma sahip olmasıdır. Bu nedenle, anket formunda kullanılan ölçeklere normallik testleri uygulanmıştır. Elde edilen verilerin normal dağılıp dağılmadığı çarpıklık ve basıklık sonucuna göre incelenmiştir ve verilerin normal dağılmadığ 1 belirlenmiştir. Çarpıklık ve basıklık katsayılarının \%5 güven aralığında istatistiksel değer aralığının $\pm 2.58, \% 1$ güven aralığı için ise bu değerin \pm 1.96 olması beklenmektedir (Liu vd., 2005; Yücenur vd., 2011). Basıklık değerinin 3'ten daha küçük değer alması veri setinin normalden daha basık olduğunu; 3'ten büyük değer alması ise normalden daha dik olduğunu göstermektedir (Pamukçu, 2017). Çarpıklık değerinin irdelenmesinde ise bu değerin sıfır olması serinin normal dağılım gösterdiğini açıklar. Şayet bu değer sıfırdan büyük ise seri pozitif $(+)$ yönde çarpık; sıfırdan küçük ise seri negatif (-) yönde çarpıktır (Şenesen, 2006).

Normallik testinin bir diğer aşaması ise Kolmogorov-Smirnov testidir. Bu testte, araştırma verilerinin dağılımı ve teorik dağılım arasındaki uyum seviyesi irdelenir. Bu testin sonuç değerinin anlamlılık düzeyinin 0.05 'in üstünde olması verilerin normal dağıldığını gösterir. Ölçeklere uygulanan normallik testi sonucunda verilerin normal dağglım göstermediği saptanmıştır. Ancak, merkezi limit teoremi gereği verilerin normal dağılım gösterdiği varsayılmıştır. $\mathrm{Bu}$ teoreme göre gözlem sayısı 30'dan fazla olan veri seti normale yakınsamaktadır (Toscano vd., 2001). Bu araştırmada da anket formu 416 katılımcıya uygulandığı için, verilerin normal dağıldığı varsayılarak, analizler ona göre yapılmıştır.

\section{Marka Kent Ölçeğinin Cinsiyet Açısından Karşılaştırılması}

Araştırmanın birinci hipotezi "H1: Marka kent algısı cinsiyete göre farklılık göstermektedir", şeklinde belirlenmiştir. Söz konusu hipotezi sınamak için bağımsız örneklem t-testi yapılmıştır (Tablo 5). 
Tablo 5. Marka Kent Ölçeğinin Cinsiyete Göre T-Testi Sonuçları $(n=416)$

\begin{tabular}{|l|l|c|c|c|c|c|}
\hline Cinsiyetiniz & & $\mathbf{n}$ & Ortalama & ss & $\mathbf{t}$ & $\mathbf{p}$ \\
\hline Marka Kent Ölçeği & Kadın & 174 & 37,15 &, 56903 &, 529 & \multirow{2}{*}{, 597} \\
\cline { 2 - 6 } & Erkek & 229 & 36,82 &, 63498 & & \\
\hline
\end{tabular}

$\mathrm{p}<0,05=$ fark var; $\mathbf{p}>\mathbf{0 , 0 5}=$ fark yok

Tablo 5'teki bulgulardan hareketle, Marka Kent Ölçeğine ilişkin algıların cinsiyet değişkeni açısından istatistiksel olarak anlamlı bir farklılık göstermediği anlaşılmaktadır ( $p>0,05)$. Bu nedenle, $\mathrm{H} 1$ hipotezi reddedilmiştir.

\section{Marka Kent Ölçeğinin Yaş Açısından Karşılaştırılması}

Araştırmanın ikinci hipotezi “H2: Marka kent alg1sı yaşa göre farklılık göstermektedir", şeklinde ortaya konmuştur. Bahsi geçen hipotezi sınamak için Kruskal-Wallis-H testi uygulanmıştır (Tablo 7).

$\mathrm{Bu}$ testte, karşılaştırılacak grup sayısı ikiden fazla olduğundan dolayı Kruskal-Wallis-H testi uygulanmıştır. Bu testteki temel varsayımlardan biri, varyansların homojen dağılım göstermesidir. Varyansların homojenliği testi Tablo 6 da verilmiş̧tir.

Tablo 6. Yaş Açısından Varyansların Homojenliği Testi

\begin{tabular}{|l|c|c|c|}
\hline Levene İstatistiği & df1 & df2 & $\mathbf{p}$ \\
\hline 1,389 & 6 & 395 &, 218 \\
\hline
\end{tabular}

Tablo 6'da verilen Levene Testi sonucuna göre, varyansların homojenliği $(p>0,05)$ koşulu sağlanmıştır, fakat yaş kategorilerinde gözlem sayısı az ve gruplar normal dağılmadığı için grupların karşılaştırılması için parametrik olmayan testlerden Kruskal-Wallis-H testi uygulanmıştır (Alpar, 2012). Bu durumda, Marka Kent Ölçeği açısından, farklı yaş grupları arasından istatistiksel olarak anlamlı bir farklılık bulunmamıştır $\left(X^{2}=6,020 ; d f=6, p>0,05\right)$. Bu sebeple, H2 hipotezi de reddedilmiştir. Analiz sonuçları Tablo 7'de görülebilmektedir.

Tablo 7. Marka Kent Ölçeğinin Yaşa Göre Kruskal-Wallis-H Testi Sonuçları

\begin{tabular}{|c|c|c|c|c|c|c|}
\hline \multirow{8}{*}{$\begin{array}{c}\text { Marka } \\
\text { Kent } \\
\text { Ölçeği }\end{array}$} & Yaş & $\mathbf{n}$ & $\begin{array}{c}\text { Sira } \\
\text { Ortalaması }\end{array}$ & $\mathbf{X}^{2}$ & df & $\mathbf{P}$ \\
\hline & 18 yaş ve altı & 16 & 173,16 & \multirow[t]{7}{*}{6,020} & \multirow[t]{7}{*}{6} & \multirow[t]{7}{*}{,421 } \\
\hline & $19-25$ yaş & 130 & 212,82 & & & \\
\hline & 26-32 yaş & 119 & 210,53 & & & \\
\hline & 33-39 yaş & 44 & 192,69 & & & \\
\hline & $40-46$ yaş & 35 & 194,11 & & & \\
\hline & 47-53 yaş & 28 & 173,57 & & & \\
\hline & $\begin{array}{l}54 \text { yaş ve } \\
\text { üzeri }\end{array}$ & 30 & 179,35 & & & \\
\hline
\end{tabular}

$\mathrm{p}<0,05=$ fark var; $\mathbf{p}>\mathbf{0 , 0 5}=$ fark yok 


\section{Marka Kent Ölçeğinin Aylık Gelir Açısından Karşılaştırılması}

Araştırmanın üçüncü hipotezi “H3: Marka kent algısı aylık gelire göre farklılık göstermektedir", şeklinde belirlenmiştir.

Bu hipotezde de karşılaştırılacak grup sayısı ikiden fazla olduğu için yine tek yönlü ANOVA testi uygulanmıştır. İlk olarak, varyansların homojenliği testinden elde edilen sonuç Tablo 8'de belirtilmiştir.

Tablo 8. Aylık Gelir Açısından Varyansların Homojenliği Testi

\begin{tabular}{|l|c|c|c|}
\hline Levene İstatistiği & df1 & df2 & p \\
\hline, 098 & 5 & 348 &, 992 \\
\hline
\end{tabular}

Tablo 8'de görülen ' $\mathrm{p}$ ' değeri 0,992 ( $\mathrm{p}>0,05)$ olduğundan, varyansların homojen olduğu görülmektedir. Bu grupların karşılaştırılması için tek yönlü ANOVA testi uygulanmıştır. ANOVA testi sonuçlarına bakıldığında, Marka Kent Ölçeği bakımından, farklı aylık gelire sahip gruplar arasında istatistiksel olarak anlamlı bir farklılık bulunmamıştır $(p>0,05)$. Buradan hareketle, H3 hipotezinin de reddedildiği ortaya çımıştır. Analiz sonuçları Tablo 9'da verilmiştir.

Tablo 9. Marka Kent Ölçeğinin Aylık Gelire Göre Tek Yönlü ANOVA Sonuçları

\begin{tabular}{|c|c|c|c|c|c|c|}
\hline \multirow{7}{*}{$\begin{array}{l}\text { Marka } \\
\text { Kent } \\
\text { Ölçeği }\end{array}$} & Aylık Gelir & $\mathbf{n}$ & Ortalama & ss & $\mathbf{F}$ & $\mathbf{P}$ \\
\hline & 1500 TL ve altı & 89 & 3,6691 & 62528 & \multirow{6}{*}{0,71} & \multirow[t]{6}{*}{,996 } \\
\hline & $1501-2500 \mathrm{TL}$ & 50 & 3,7243 & ,59053 & & \\
\hline & $2501-3500 \mathrm{TL}$ & 63 & 3,6717 &, 59623 & & \\
\hline & $3501-4500 \mathrm{TL}$ & 67 & 3,6952 & 60974 & & \\
\hline & $4501-5500 \mathrm{TL}$ & 41 & 3,6848 & 64397 & & \\
\hline & 5501 TL ve üzeri & 44 & 3,6621 & ,70527 & & \\
\hline
\end{tabular}

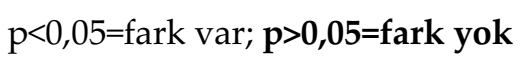

\section{Marka Kent Ölçeğinin Eğitim Durumu Açısından Karşılaştırılması}

Marka Kent Ölçeği ile ilgili uygulanan bir diğer karşılaştırma ise eğitim durumu değişkeni açısından yapılmıştır. Söz konusu hipotez "H4: Marka kent algısı eğitim durumuna göre farklılık göstermektedir", şeklinde belirlenmiştir.

Yine, burada da karşılaştırılacak grup sayısı ikiden fazla olduğu için Kruskal-Wallis-H testi uygulanmıştır. Varyansların homojenliği testinin sonucu Tablo 10'da gösterilmektedir.

Tablo 10. Eğitim Durumu Açısından Varyansların Homojenliği Testi

\begin{tabular}{|l|c|c|c|}
\hline Levene İstatistiği & df1 & df2 & p \\
\hline 1,435 & 6 & 391 &, 200 \\
\hline
\end{tabular}


Tablo 10'daki Levene Testi sonucuna göre, varyans homojenliği $(p>0,05)$ sağlanmıştır, ancak eğitim durumu kategorilerinde gözlem sayısı az ve gruplar normal dağılmadığı için grupların karşılaştırılması için parametrik olmayan testlerden Kruskal-Wallis-H testi kullanılmıştır (Alpar, 2012). Tablo 11'de de görüldüğü gibi Marka Kent Ölçeği bakımından, farklı eğitim durumları arasında istatistiksel olarak anlamlı bir farklılığın bulunmadığı saptanmıştır $\left(X^{2}=8,765 ; \mathrm{df}=7, \mathrm{p}>0,05\right)$. Bu nedenle, $\mathrm{H} 4$ hipotezi reddedilmiştir.

Tablo 11. Marka Kent Ölçeğinin Eğitim Durumuna Göre Kruskal-Wallis-H Testi Sonuçları

\begin{tabular}{|l|l|c|c|c|c|c|}
\hline $\begin{array}{l}\text { Marka } \\
\text { Kent } \\
\text { Ölçeği }\end{array}$ & Eğitim Durumu & $\mathbf{n}$ & $\begin{array}{c}\text { Sira } \\
\text { Ortalaması }\end{array}$ & $\mathbf{X}^{2}$ & $\mathbf{d f}$ & $\mathbf{P}$ \\
& $\begin{array}{l}\text { Okuma yazma } \\
\text { bilmiyorum }\end{array}$ & 1 & 199,00 & 8,765 & 7 &, 270 \\
& İlkokul & 9 & 136,78 & & & \\
& Ortaokul & 20 & 243,68 & & & \\
& Lise & 94 & 212,80 & & & \\
& Ön lisans & 51 & 204,63 & & & \\
& Lisans & 175 & 190,70 & & & \\
& Yüksek lisans & 42 & 203,56 & & & \\
& Doktora & 7 & 162,14 & & & \\
\hline
\end{tabular}

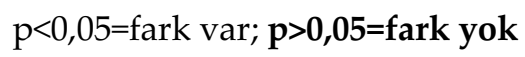

\section{Korelasyon Testleri}

Korelasyon analizi, iki ifade arasındaki doğrusal ilişkiyi veya herhangi bir değişkenin 2 ya da 2'den fazla değişken ile olan ilişkisini test etmek, varsa bu ilişkinin seviyesini sinamak amaciyla kullanılan istatistiksel bir tekniktir. Buradaki temel amaç, bağımsız değişken $(X)$ değiştiğinde, bağımlı değişkenin (Y) hangi yönde farklılaşacağını belirlemektir (Kalaycı, 2010). Değişkenler arasındaki bu ilişkinin yönünü ve kuvvetini ifade eden sayıya da korelasyon katsayısı denilmektedir (Lorcu, 2015). Korelasyon katsayısı (r), iki değişken arasındaki ilişkinin ne ölçüde var olduğunu gösterir ve -1 ile +1 arasında değişim gösterir. Korelasyon katsayısının gücüne ilişkin açılamalar Tablo 12' de verilmektedir (Köse, 2008):

Tablo 12. Korelasyon Katsayısı ve İlişkisi

\begin{tabular}{|l|l|}
\hline Korelasyon Katsayısı & İlişki \\
\hline $0,00-0,25$ & Çok zayıf \\
\hline $0,26-0,49$ & Zayıf \\
\hline $0,50-0,69$ & Orta \\
\hline $0,70-0,89$ & Yüksek \\
\hline $0,90-1,00$ & Çok yüksek \\
\hline
\end{tabular}

Algılanan Kalite, Algılanan Değer, Destinasyon İmajı ve Memnuniyet ölçekleri arasındaki ilişkilere yönelik korelasyon analizi sonucuna bakıldığında, Algılanan Kalite ve Algılanan Değer arasında orta düzeyde, pozitif yönlü istatistiksel olarak anlamlı bir ilişki bulunmuş iken (r (416) =0,640 ve $\mathrm{p}=0,000)$; Algılanan Değer ile Destinasyon İmajı arasında yüksek düzeyde, pozitif yönlü 
istatistiksel olarak anlamlı bir ilişki tespit edilmiştir ( $(416)=0,715$ ve $\mathrm{p}=0,000)$. Destinasyon İmajı ile Memnuniyet arasında da yüksek düzeyde, pozitif yönlü istatistiksel olarak anlamlı bir ilişki görülmüştür (r (416)=0,724 ve p=0,000). Bu durumda, H5, H6 ve H7 hipotezleri kabul edilmiştir.

Genel bir değerlendirme yapabilmek maksadıyla, Destinasyon Markalaşma Süreci'nde yer alan "Algılanan Kalite", "Algılanan Değer", "Destinasyon İmajı" ve "Memnuniyet" ölçeklerinde ifadeler bir arada toplanarak, Marka Kent ölçeği ile arasındaki ilişkiye de bakılmıştır. Elde edilen sonuçlardan hareketle, süreç ile çıktı arasında zayıf düzeyde, pozitif yönlü, istatistiksel olarak anlamlı bir ilişki bulunmuştur ( $\mathrm{r}(416)=0,444$ ve $\mathrm{p}=0,000$ ). Bu sonuca göre, H8 hipotezi kabul edilmiştir. H8 hipotezine bağlı olarak geliştirilen 8 alt hipotezle ilgili sonuçlarda şu şekildedir:

- Algilanan Kalite Ölçeği ile Marka Kent Ölçeği'nin Kültürel Açıdan Marka Kent Boyutu arasında zayıf düzeyde, pozitif yönlü, istatistiksel olarak anlamlı bir ilişki tespit edilmiştir ( $\mathrm{r}(416)=0,463$ ve $\mathrm{p}=0,000)$.

- Algılanan Kalite Ölçeği'nin, Marka Kent'in diğer bir boyutu olan Stratejik Açıdan Marka Kent arasında çok zayıf düzeyde, pozitif yönlü, istatistiksel olarak anlamlı bir ilişki bulunmuştur ( $(416)=0,118$ ve $\mathrm{p}=0,016)$.

- Algılanan Değer ile Kültürel Açıdan Marka Kent arasında zayıf düzeyde, pozitif yönlü, istatistiksel olarak anlamlı bir ilişki bulunmuştur ( $(416)=0,316$ ve $p=0,000)$.

- Algılanan Değer ile Stratejik Açıdan Marka Kent arasında zayıf seviyede, pozitif yönlü, istatistiksel olarak anlamlı bir ilişki saptanmıştır $(\mathrm{r}(416)=0,244$ ve $\mathrm{p}=0,000)$.

- Destinasyon İmajı ile Kültürel Açıdan Marka Kent Boyutu arasında zayıf seviyede, pozitif yönlü, istatistiksel olarak anlamlı bir ilişki görülmüştür (r $(416)=0,356$ ve $p=0,000$ ).

- Destinasyon İmajı ile Stratejik Açıdan Marka Kent Boyutu arasında çok zayıf düzeyde, pozitif yönlü, istatistiksel olarak anlamlı bir ilişki bulunmuştur (r (416) $=0,203$ ve $p=0,000)$.

- Memnuniyet Ölçeği ile Kültürel Açıdan Marka Kent Boyutu arasında zayıf düzeyde, pozitif yönlü, istatistiksel olarak anlamlı bir ilişki bulunmuştur $(r(416)=0,313$ ve $p=0,000)$.

- Memnuniyet ile Stratejik Açıdan Marka Kent Arasında çok zayıf düzeyde, pozitif yönlü, istatistiksel olarak anlamlı bir ilişki bulunmuştur ( $(416)=0,237$ ve $p=0,000)$.

Bu sonuçlardan hareketle, H8a, H8b, H8c, H8d, H8e, H8f, H8g ve H8h alt hipotezlerinin de kabul edildiği belirlenmiştir.

\section{Şanlıurfa'nın Marka Kent Olmasına Dair Frekans Analizi}

Bir sonraki aşamada katılımclara, 'Sizce Şanlıurfa bir marka kent midir?' şeklinde bir soru yöneltilmiş ve söz konusu soruya Tablo 13 'te belirtildiği üzere katılımcıların 238 'inin $(\% 57,2)$ 'Evet', 77'sinin (\%18,5) 'Hayır'; 91'inin (\% 21,9) ise 'Fikrim yok' şeklinde cevap verdikleri tespit edilmiştir.

Tablo 13. Şanlıurfa'nın Marka Kent Olmasına Dair Frekans Analizi

\begin{tabular}{|l|c|c|}
\hline & $\mathbf{n}$ & $\mathbf{\%}$ \\
\hline Evet & 238 & 57,2 \\
\hline Hayır & 77 & 18,5 \\
\hline Fikrim yok & 91 & 21,9 \\
\hline Yanitsiz & 10 & 2,4 \\
\hline Toplam & $\mathbf{4 1 6}$ & $\mathbf{1 0 0 , 0}$ \\
\hline
\end{tabular}




\section{Şanlıurfa İçin Logo Planlamasına İlişkin Görüşler}

Katılımcılara, "Şanlıurfa için bir logo oluşturulacak olsa, sizce Şanlıurfa ile ilgili hangi öğeleri içermelidir?" sorusu sorulduğunda, Balıklıgöl, Göbeklitepe, Harran, Fırat, Urfa Kalesi, Çiğköfte, Ceylan, İsot, Fıstık, Kelaynak, Ciğer, Biber, Kubbe Evler, T harfi (Göbeklitepe) ve Güneş unsurlarının ifade edildiği belirlenmiştir. Böylece, verilen cevaplardan hareketle katılımcıların Şanlıurfa'ya dair logo fikirlerinin belirlenmesinde, kente özgü yeme-içme, tarih, inanç vb. kapsamındaki öğelerin daha çok ön plana çıtı̆̆ı görülmektedir.

\section{Şanlıurfa İçin Slogan Planlamasına İlişkin Görüşler}

Örneklemi oluşturan gruba, "Şanlıurfa için bir slogan oluşturulacak olsa, sizce nasıl olmalıdır?" sorusu sorulduğunda, verilen cevaplar arasında "Ciğer, Patlıcan ve İsot", "Kim Olursan Ol Gel”, "Sarı Sıcak", "Medeniyetler Beşiği”, "Tarih İçeren Bir Şeyler", “ìlk Yerleşim, İlk Yaşam, İlk Tadlar”, "Peygamberler Şehri”, "Kültür Kazanı”, “Hz. İbrahim'in Şehri”, “Ateşin Suya Düştüğü Şehir", "Mezopotamya'nın Kalbi", “Tarihin İlk Sayfaları", "Geçmişiyle Yarına Hazır" ve "Saklı Cennet" sloganlarının sıkça ifade edilenler arasında yer aldıkları saptanmıştır. Katılımcıların Şanlıurfa sloganıyla ilgili verdikleri cevapların daha çok kültür, inanç ve medeniyet konulu oldukları göze çarpmaktadır. Bu durumun Şanlıurfa'nın eski bir şehir olması açısından şehirle örtüştüğü düşünülmektedir.

\section{Model Önerisi}

$\mathrm{Bu}$ araştırmanın temel amaçlarından bir diğeri, Şanlıurfa'nın destinasyonda markalaşabilmesi için bir model önerisi ortaya koymaktır. Bu nedenle, Şekil 1'de gösterilen "Destinasyon Markalaşma Süreci" ile Şekil 2'de belirtilen "Destinasyon Markalaşması" modelleri için korelasyon (ilişkisel) testleri yapılmıştır.

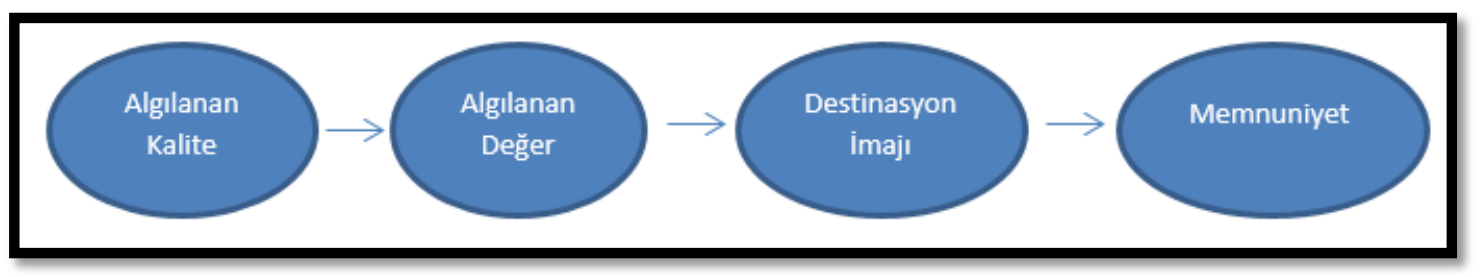

Şekil 1. Destinasyon Markalaşma Süreci Modeli

Destinasyon Markalaşma Süreci isimli, Şekil 1'de de gösterilen modelin testi için H5, H6 ve H7 hipotezleri test edilmiştir. Bu modelde, öncelikle algılanan kalite ile algılanan değer; ardından algilanan değer ile destinasyon; son olarak da destinasyon imajı ile memnuniyet arasındaki ilişkiler sınanmıştır. Bu ölçekler arasında sırasıyla orta, yüksek, yüksek derecede pozitif yönlü istatistiksel olarak anlamlı ilişkiler olduğu belirlenmiştir. 


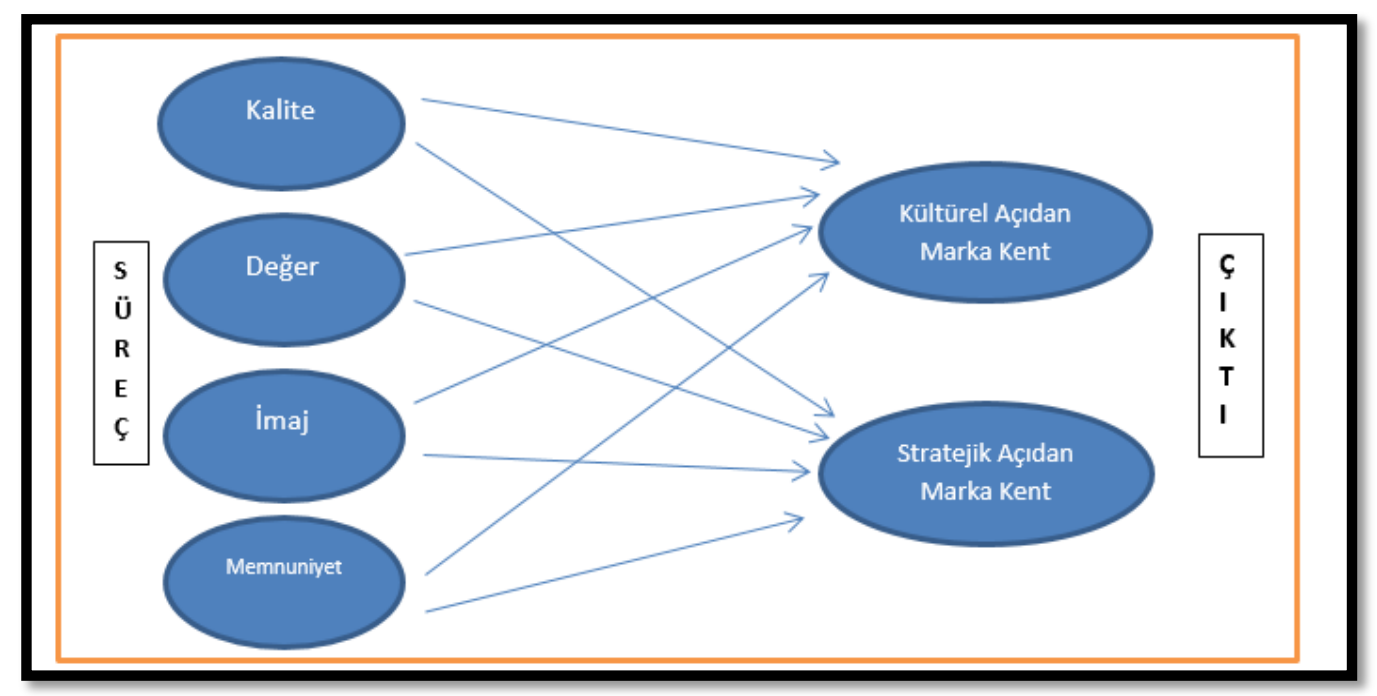

Şekil 2. Destinasyon Markalaşması Modeli

Şekil 2'de görüleceği üzere, Şanlıurfa için bir öneri niteliği taşıyacak olan modeli ise H8 ana hipotezi ve alt hipotezler sinamıştır. Bu noktada, Algılanan Kalite, Algzlanan Değer, Destinasyon Imajı ve Memnuniyet ölçeklerinin oluşturduğu Destinasyon Markalaşma Süreci ile Kültürel Açıdan Marka Kent ve Stratejik Açıdan Marka Kent şeklinde 2 boyuttan oluşan Marka Kent Ölçeği arasındaki ilişki test edilmiştir. Bu modelde de anlamlı ilişkiler ortaya çıkmıştır. Testlerin sonuçlarıyla ilgili ayrıntılar, 'Korelasyon Testleri' bölümünde verilmiştir. Böylece, her iki modelin de kabul edildiği uygulanan testler sonrasında ortaya konmuştur.

Tüm bunlara ek olarak, Şanlıurfa'nın destinasyonda markalaşmasıyla birlikte;

- Daha kaliteli hizmet sunan turizm tesislerinin inşa edilmesi,

- İstihdama katkı sağlanması,

- Turizm sektöründe yerli ve yabancı yatırımların artması,

- Yerel halkın misafirperver yaklaşımının şehrin turizmde markalaşmasıyla birlikte daha fazla ön plana çıması,

- Hem iç hem de dış pazardan ziyaretçinin Şanlıurfa'ya gelmesi,

- Ziyaretçilerin şehrin sahip olduğu birçok turizm noktasını ziyaret etmek için daha fazla konaklamaları,

- Şehrin sahip olduğu turistik ürünlerin bilinirliğinin artması,

- Şanlıurfa'nın markalaşması ile birlikte Güneydoğu Anadolu Bölgesi'nde yer alan Gaziantep, Mardin ve Diyarbakır gibi illere de turistik talebin artması şeklinde durumların da ortaya çıkabileceği öngörülmektedir.

\section{TARTIŞMA, SONUÇ VE ÖNERİLER}

Destinasyon markalaşması ile ilgili araştırmalar, özellikle yurtdışında daha eskiye dayanmaktadır. Türkiye'de ise, daha yeni yeni etraflıca irdelenmeye başlanan bir konu halini almıştır. Yapılan araştırmalara göz atıldığında, bunların daha çok bir şirketin kıymetli marka varlıklarını tanımlama ve bunların pazarlama hedefleri ve girişimleri konusunda yapıldığ görülmektedir (Delgado-Ballester ve Munuera-Aleman, 2000; d'Hausteserre, 2001; Pritchard ve Morgan, 2001; Morgan vd., 2002; Back ve Parks, 2003; Kwun ve Oh, 2004; Kocaman ve Güngör, 
2012; Şahin, 2015). Bunun yanında, rekabetçilik üzerine de araştırmaların var olduğu saptanmıştır (Kaplanidou ve Vogt, 2003; Göktaş, 2016). Öte yandan destinasyon markalaşması denildiğinde, bunu anlamak için genelde destinasyon imajı kavramı kullanılmıştır (Edwards vd., 2000; Pritchard ve Morgan, 2001; Hall vd., 2001; Papadopoulos ve Heslop, 2002; Cai, 2002; Hankinson, 2004; Hankinson, 2005; Boo, 2006; Campelo vd., 2014; Oliveira ve Panyik, 2015; Kladou vd., 2017). Bunun yanında, Ooi'ye (2004) göre birçok destinasyon markalaşması araştırmaları marka imajı ve mesajlarının nasıl hazırlandığının ve sunulduğunun üzerinde durmuşlardır. Bu araştırmada ise, yukarıda bahsedilen konulardan ziyade, kalite, değer, memnuniyet, imaj ve marka kent hususları bir arada ele alınıp araştırmanın temelini oluşturmaktadır.

Markalaşmaya dönük gerçekleştirilen pazarlama eylemleri, tüketicinin destinasyon seçimini olumlu yönde etkilemesi bakımından destinasyon oluşturmaya yardımcı olur (Blain vd., 2005). Cai (2002), Gartner' in (1993) imaj bileşenlerine (bilişsel, duyuşsal, çaba gösteren); Keller'in (2003) ise ilişki çeşitlerine (nitelik, fayda ve tutum) dayandırarak destinasyon markalaşması adına kavramsal bir model sunmuştur. Cai (2002), marka bileşenleri karışımından, marka kimliğinden ve marka imajından oluşan dinamik bir destinasyon markalaşması sürecini göstermek istemesine rağmen, bunların oluşumu ve ölçümlerine ilişkin belirgin bir bilgi ortaya koymamıştır. $\mathrm{Bu}$ araştırma o bakımdan da farklılık göstermektedir. Araştırmada, yalnızca kavramsal bir model ortaya konulmamış olup; aynı zamanda biçimsel olarak da özgün bir model ortaya konulmaya çalışılmıştır. Her ne kadar daha önceki araştırmalar bir sonrakilerin bir anlamda çekirdeğini oluştursa da imaj oluşturma, tam manasıyla markalaştırma anlamına gelmemektedir. Markalaşmada, bir destinasyon kendisini rakiplerinden farklılaştıran bir imaj oluşturduktan sonra diğer destinasyon marka unsurlarına dayandırılabilir (Kaplanidou ve Vogt, 2003). İmaj, markalaşmaya bir adım yakındır, fakat bu kapsamda kalite, değer, memnuniyet kavramları da bu bütünün birer parçasıdır. Destinasyon imajı araştırmalarını markalaşma seviyesine getirmek için de bunlar arasında bağlantı kurulması önemlidir (Hem ve Iverson, 2004). Bu nedenle, markalaşma süreci içerisinde değerlendirilen "algılanan kalite, algılanan değer, destinasyon imajı, memnuniyet" ölçekleri ve "marka kent" ölçeği arasındaki ilişkinin yönü ve kuvveti ortaya konmaya çalışılmıştır.

Destinasyon markalaşması konusunda, yerli yazında da geniş anlamda araştırmalar hız kazanmıştır. Göker (2018), ziyaretçilerin markalaşmış bir destinasyona yönelik beklenti düzeylerini ölçmüştür. 2014 yılında yapılan bir araştırmada ise, bir yerin doğal ve kültürel kaynaklarının o destinasyonun markalaşma sürecine olumlu katkı yapıp yapmadığ 1 sorgulanmıştır (Kaya, 2014). İbiş (2017) ise, Bergama'nın markalaşma sürecini, Bergama kapsamında yer alan kültür, termal ve kırsal turizm unsurlarının Bergama'nın destinasyon markalaşmasında ne derece kullanıldığını araştırmıştır. Çanakkale ve İzmir illerine yönelik yapılan araştırmada ise, ziyaretçilerin bu destinasyonlara yönelik marka algıları ölçülmüştür (Kocaman, 2017). Çanakkale merkezli yapılan başka bir araştırmada ise, Çanakkale'nin markalaşması yolunda ilde yapılan etkinliklerin markalaşmaya etkisi incelenmiştir (Altınışı, 2017).

$\mathrm{Bu}$ araştırmada ise 5 farklı ölçek kullanılmıştır. Bunlar; algılanan kalite, algılanan değer, memnuniyet, destinasyon imajı ve marka kenttir. Marka kent ölçeği, daha önce herhangi bir araştırmada kullanılmamış olup, yazarlar tarafından geliştirilmiştir. 5 ölçek arasındaki ilişkinin yönü ve kuvveti incelenmiş ve sonunda özgün bir model ortaya konmaya çalışılmıştır. Ayrıca, bu biçimsel modelden ve anket formunda yer alan diğer sorulara verilen cevaplardan hareketle Şanlıurfa'nın turizmde markalaşması adına bazı öneriler geliştirilmiştir. Özellikle bu açıdan, araştırmanın destinasyon markalaşması ve Şanlıurfa ile ilgili yapılan araştırmalardan tamamıyla farklılık gösterdiği düşünülmektedir. Bunun yanında, konunun amacına uygun olarak 
katılımcılara logo-slogan önerisi ve kendilerinin şehri marka kent olarak görüp görmedikleri şeklinde sorular da yöneltilmiştir.

Şanlıurfa'nın destinasyonda markalaşabilmesi amacıyla yapılan bu araştırmada, önemli başka bulgulara rastlanmıştır. Şanlıurfa'yı ziyaret eden katılımcıların daha çok genç ve eğitimli; aynı zamanda düşük gelire sahip oldukları belirlenmiştir. Ziyaretçilerin birçoğunun İstanbul'dan geldikleri saptanmıştır. Katılımcıların yarıdan fazlası Şanlıurfa'nın bir marka kent olduğunu ifade etmişlerdir. Markalaşma yolunda, logo ve slogan önerilerinde de Balıklıgöl, Göbeklitepe, Urfa Kalesi, İlk Yaşam, İlk Yerleşim, Medeniyet gibi unsurların ön plana çıtığı belirlenmiştir.

Anket formunda kullanılan Algılanan Kalite, Algılanan Değer, Destinasyon İmajı, Memnuniyet ve Marka Kent ölçeklerinde yer alan ifadelere verilen cevapların ortalamalarının yüksek olması, Şanlıurfa'nın markalaşma yolunda olumlu yönde değişim gösterdiğini açılamaktadır. Ancak, elde edilen veriler içerisinde düşük ortalamalara sahip ifadelerin de bulunduğu görülmüştür. Örneğin, katılımcılar Şanlıurfa'da gece hayatının iyi olmadığını belirtmişlerdir. Bu durum, Anadolu kentlerinin birçoğunda benzer şekilde yaşanmaktadır. Bunun yanında, katılımcılar yerel halkın kültürel değeri ve korunması konusunda yeteri kadar bilinçli olmadığı, şehrin zengin kültürel mirasını vurgulayan ulusal ve uluslararası düzeyde tanıtım ve pazarlamasının daha etkili yapılması gerektiğini vurgulamışlardır. Buradan hareketle, düşük ortalamaya sahip ifadelerin güçlendirilmesine dönük şehrin farklı paydaşlarının kolektif bir çalışma yapmaları da önem taşımaktadır.

Araştırmanın sonunda elde edilen verilerden de hareketle, kamuya ve özel sektöre yönelik öneriler sıralanabilir. Kamuya yönelik öneriler şu şekildedir:

- İl Kültür ve Turizm Müdürlüğü öncülüğünde, kamu sektörü, özel sektör, akademi ve ilgili sivil toplum kuruluşlarının katılımıyla, markalaşma çalışmaları ortak akıl ile yürütülmelidir.

- Kentin turizmde markalaşması adına, yerel yönetimler iş birliğiyle yerel halkın bu konuda bilinçlendirilmesine yönelik seminerler düzenlenmeli, basılı ve elektronik ortamda konuyla ilgili bilgilendirmeler yapılmalıdır.

- Üniversite ve İl Kültür Turizm Müdürlüğü iş birliğiyle turizm noktasında hizmet veren işletmelere, markalaşma yolunda teorik ve uygulamalı turizm eğitimleri verilmelidir.

- Gelen turist sayısının ve ekonomik girdinin artırılmasına yönelik ne yapılması gerektiği noktasında kamu ve özel sektör temsilcileri bir araya gelmelidir.

- Restorasyon çalışmaları amacına uygun ve özgünlüğe en az biçimde zarar vererek yapilmalıdir.

- Şayet yapılmıyorsa, turizm eğitimi alan lise ve üniversite öğrencileri için şehir merkezine dönük uygulamalı geziler artırılmalıdır.

- Şehri ziyaret edenlerin yarısından çoğunun 19-32 yaş aralığında olmasından dolayı, bu yıl üçüncüsü düzenlenecek olan Şanlıurfa Gençlik Festivali (Festivall, 2019) tarzında daha çok gençleri hedef alan faaliyetler artırılmalıdır.

- Şanlıurfa'yı ziyaret eden turist profilinin çoğunun lisans eğitimi mezunu olduğu göz önünde bulundurulduğunda, 2018 yılında düzenlenen Şanlıurfa 2. Ulusal Kitap Fuarı (Şanlıurfa Büyükşehir Belediyesi, 2018) gibi etkinlikler artırılmalıdır.

- Özellikle Balıklıgöl, Göbeklitepe, Harran, Fırat, Urfa Kalesi, Çiğköfte, Ceylan, İsot, Fıstık, Kelaynak, Ciğer, Biber, Kubbe Evler, T harfi (Göbeklitepe), Güneş gibi unsurların ön plana çıktığı bir logo tasarlanmalıdır.

- 'Kim Olursan Ol Gel', 'Sarı Sıcak', 'Medeniyetler Beşiği', 'Illk Yerleşim, İlk Yaşam, İlk Tadlar', 'Peygamberler Şehri', 'Kültür Kazanı', 'Hz. İbrahim'in Şehri', 'Ateşin Suya Düştüğü Şehir', 'Mezopotamya'nın Kalbi', 'Tarihin İlk Sayfaları', 'Geçmişiyle Yarına Hazır' gibi ifadelerin yer alacağı bir slogan hazırlanmalıdır. 
- Katılımcıların çoğunluğunun gençlerden oluşmasından dolayı, 2018 yılında gerçekleştirilen "Avrupa Gençlik Spor Festivali” türünden faaliyetler devam etmelidir (Urfa, 2018).

- Araştırmadan elde edilen bulgular ışığında, yerel halk kültürel mirasın korunması konusunda bilinçlendirilmelidir.

- Kültürel mirası vurgulayan ulusal ve uluslararası düzeyde tanitım ve pazarlama faaliyetleri geliştirilmeli ve artırılmalıdır.

Ülkelerin herhangi bir endüstri dalında başarıya ulaşabilmesi için, kamunun olduğu kadar özel sektörün de rolü büyüktür. Destinasyonda markalaşma konusunda Şanlıurfa örneğinde, özel sektöre yönelik öneriler aşağıdaki gibi geliştirilmiştir:

- Genelde düşük ve orta gelirli bireylerin kenti ziyaret ettiği düşünüldüğünde, turizm ürünlerinde belirlenecek fiyatlar da buna göre düzenlenmelidir.

- Turistik tesislerin uluslararası standartlarda daha iyi hizmet vermesi sağlanmalıdır.

- İşletmeler kurum içi eğitime daha fazla eğilmeli ve hizmet kalitesinin arttırılmasına yönelik çalışanlara yönelik eğitim programları düzenlemelidir.

- Gece hayatının canlanmasına yönelik, alternatif rekreasyon merkezleri açılmalıdır.

- Katılımcılarının çoğunluğunu genç nüfusun oluşturduğu ve "Gece hayatı iyidir." ifadesine verilen cevapların ortalamasının 2,82 olduğu göz önünde bulundurularak, Şanlıurfa'daki gece eğlenceleriyle ilgili kurumsal yatırımlar arttırılmalıdır.

Şanlıurfa'nın destinasyonda markalaşması için öncelikle bu konuda yapılmış araştırmaların çıktıları da dikkate alınarak, konunun şehrin çeşitli paydaşları tarafından tartışılması ve bir yol haritası çıkarılmasının kente sosyal, ekonomik ve kültürel anlamda fayda sağlayacağı dikkate alınmalıdır. Süreç içerisinde markalaşma sağlandığı takdirde, şehrin bilinirliğinin artması, hizmet kalitesinin daha iyi bir noktaya gelmesi, eldeki mevcut imkânların etkili ve planlı kullanılması, maddi getirinin ve ziyaretçilerin memnuniyet düzeyinin artması gibi çıktıları gerçekleşecektir.

\section{KAYNAKÇA}

Aaker, D. (1991). Managing Brand Equity. New York: John Wiley \& Sons Inc.

Akbıyık, M. (2014). Şanlıurfa İlinin Turizm Potansiyelinin Belirlenmesi ve Planlamaya Yönelik Öneriler, Yayınlanmamış Doktora Tezi, Atatürk Üniversitesi, Erzurum.

Alpar, R. (2012). Uygulamalı İstatistik ve Geçerlilik-Güvenirlik. Ankara: Detay Yayıncılık.

Altınışık, Ö. (2017). Etkinliklerin Destinasyon Markalaşmasına Etkisi: Çanakkale 100.Yıl Etkinlikleri Örneği, Yayınlanmamış Yüksek Lisans Tezi, Çanakkale Onsekiz Mart Üniversitesi, Çanakkale.

Arslan, M. (2012). Araştırma Yöntem ve Teknikleri. [Çevirimiçi] http://celalkaraca.com/dersler/bahar/Arastirma_Yontem_Teknikleri/arastirma_yontem_ve_tekni kleri.pdf [Erişim tarihi: 16.04.2019].

Back, K.-J., and Parks, S. C. (2003). A Brand Loyalty Model Involving Cognitive, Affective and Conative Brand Loyalty and Customer Satisfaction, Journal of Hospitality and Tourism Research, $27(4), 419-435$.

Blain, C., Levy, S. E. and Ritchie, R. B. (2005). Destination Branding: Insights and Practices from Destination Management Organizations, Journal of Travel Research, 43: 328-338. 
Boo, S. (2006). Multidimensional Model of Destination Brands: An Application of Customer-Based Brand Equity, Unpublished Doctorate Thesis, University of Nevada, Las Vegas.

Buhalis, D. (2000). Marketing the Competitive Destination of the Future, Tourism management, 21(1): 97-116.

Büyüköztürk, Ş., Kılıç Çakmak, E., Akgün, Ö.A., Karadeniz, Ş. ve Demirel, F. (2008). Bilimsel Araştırma Yöntemleri. Ankara: Pegem Akademi.

Cai, L. A. (2002). Cooperative Branding for Rural Destinations, Annals of Tourism Research, 29(3): 720-742.

Campelo, A., Aitken, R., Thyne, M., and Gnoth, J. (2014). Sense of Place: The Importance for Destination Branding, Journal of Travel Research, 53(2): 154-166.

Clifton, R. (2003). The Future of Brands, (Editor) Clifton vd.: In Brands and Branding (p. 227-241). NJ: Bloomberg Press.

Çelik, M. (2017). Şanlıurfa'daki Gastronomi Kültürünün, Kenti Ziyaret Eden Yerli Turistlerin Kalış Sürelerine Etkisi Üzerine Bir Araştırma, Yayınlanmamış Yüksek Lisans Tezi, Gazi Üniversitesi, Ankara.

D'Hauteserre, A. M. (2001). Destination Branding in a Hostile Environment, Journal of Travel Research, 39, 200-207.

Delgado-Ballester, E. and Munuera-Aleman, J. L. (2000). Diners Perceptions of Quality, Value and Satisfaction, Cornel; Hotel and Restaurant Administration Quarterly, 41(3), 58-82.

Deslandes, D. D. (2003). Assessing Consumer Perceptions of Destinations: A Necessary First Step in the Destination Branding Process, Unpublished Doctorate's Thesis, The Florida State University, Florida.

Dredge, D. and Jenkins, J. (2003). Destination Place Identity and Regional Tourism Policy, Tourism Geographies, 5(4): 383-407

Edwards. J., Fernandes, C., Fox, Julian and Vaughan, R. (2000). Tourism Brand Attributes of the Alto Minho, Portugal, (Editor) Richards, G. and Hall, D.: In Tourism and Sustainable Community Development (p. 285-296). New York; Rutledge.

$\begin{array}{llllll}\text { Festivall. (2019). Şanlıurfa Gençlik } & \text { 3. Festivali. } & \text { [Çevirimiçi] }\end{array}$ https:/festivall.com.tr/festival/1623/sanliurfa-genclik-festivali/ [Erişim tarihi: 26.06.2019].

Gartner, W. (1993). Image Formation Process, Journal of Travel and Tourism Marketing, 2(2/3): 191215.

Göker, G. (2018). Açık Alanda Yapılan Doğa Temelli Rekreatif Etkinlikler ve Destinasyon Markalaşması (Ilgaz Dağı Milli Parkı Örneği), Yayınlanmamış Doktora Tezi, Gazi Üniversitesi, Ankara.

Göktaş, L. S. (2016). Şanlıurfa ve Konya İllerinin İnanç Turizmi Potansiyelleri ve Halkın İnanç Turizmine Bakış Açısından İki İlin Karşılaştırılması, Yayınlanmamış Yüksek Lisans Tezi, Selçuk Üniversitesi, Konya.

Gyimothy, S. (2000). Branding in Tourism and Hospitality Management. Institute for Service Management. [Online] http://www.humsamf.auc.dk/edu/snf/turime/ [Accessed: 11.10.2005].

Hall, J., Robertson, N. and Shaw, M. (2001). An Investigation of Perceived Value and Consumable Goods, Asia Pacific Advances in Consumer Research, 42(2): 23-31. 
Hankinson, G. (2004). Relational network brands: Towards a Conceptual Model of Place Brands, Journal of Vacation Marketing, 10(2): 109-121.

Hankinson, G. (2005). Destination Brand Images: A Business Tourism Perspective, Journal of Services Marketing, 79(1): 24-32.

Hem, L. E. and Iversen, N. M. (2004). How to Develop a Destination Brand Logo: A Qualitative and Quantitative Approach, Scandinavian Journal of Hospitality and Tourism, 4(2): 83-106.

İbiş, T. (2017). Destinasyon Markalaşmast Sürecinde Turizmin Önemi: Bergama Örneği, Yayınlanmamış Yüksek Lisans Tezi, Ege Üniversitesi, İzmir.

İçöz, O. (2005). Hizmet Pazarlaması. Ankara: Turhan Kitabevi.

Jago, L., Chalip, L., Brown, G., Mules, T. and Ali, S. (2003). Building Events into Destination Branding: Insights from Experts, Event Management, 8: 3-14.

Kalayc1, Ş. (2010). SPSS Uygulamalı Çok Değişkenli İstatistik Teknikleri. Ankara: Asil Yayın.

Kaplanidou, K. and Vogt., C. (2003). Destination Branding: Concept and Measurement. Travel Michigan and Michigan State University, Department of Park, Recreation and Tourism Resources, $1-7$.

Karasar, N. (1995). Bilimsel Araştırma Yöntemi. Ankara: 3A Araştırma Eğitim Danışmanlık Ltd. Şti.

Kaya, F. (2014). Destinasyon Markalaşması Sürecinde Doğu Karadeniz Bölgesi'nin Doğal ve Kültürel Kaynaklar Açısından Değerlendirilmesi, Yayınlanmamış Yüksek Lisans Tezi, İstanbul Üniversitesi, İstanbul.

Keller, K. L. (2003). Strategic Brand Management: Building, Measuring, and Managing Brand Equity. NJ: Prentice-Hall.

Kladou, S., Kavaratzis, M., Rigopoulou, I., and Salonika, E. (2017). The Role of Brand Elements in Destination Branding, Journal of Destination Marketing E Management, 6(4): 426-435.

Knowles, J. (2001). The Role of Brands in Business, (Editor) Goodchild, J. and Callow C.: In Brands: Visions and Values. Chichester: John Wiley \& Sons.

Kocaman, S., ve Güngör, İ. (2012). Destinasyonlarda Müşteri Temelli Marka Değerinin Ölçülmesi ve Marka Değeri Boyutlarının Genel Marka Değeri Üzerindeki Etkileri: Alanya Destinasyonu Örneği, Journal of Alanya Faculty of Business/Alanya İşletme Fakültesi Dergisi, 4(3).

Kocaman, G. (2017). Destinasyon Markalaşmasının Memnuniyet Üzerine Etkisi: İzmir Efes Antik Müzesi ve Çanakkale Gelibolu Tarihi Milli Parkı Alanları Üzerine Bir Araştırma, Yayınlanmamış Yüksek Lisans Tezi, Atatürk Üniversitesi, Erzurum.

Köse, S. K. (2008). Korelasyon ve regresyon analizi. [Çevirimiçi] http://tr. scribd. com/doc/2066772/korelasyon-analizi [Erişim tarihi: 10.04.2018].

Krejcie, R. V. and Morgan, D. W. (1970). Determining Sample Size for Research Activities, Educational and Psychological Measurement, 30(3): 607-610.

Kuvvetli, M. (2014). Turizmde Destinasyon Markalaşması: Şanlıurfa Üzerinde Bir Uygulama, Yayınlanmamış Yüksek Lisans Tezi, Niğde Üniversitesi, Niğde.

Kwun, J. W., and Oh, H. (2004). Effects of Brand, Price, and Risk on Customers' Value Perceptions and Behavioral Intentions in the Restaurant Industry, Journal of Hospitality \& Leisure Marketing, 77(1), 31-49.

Laws, E. (1995). Tourist Destination Management: Issues, Analysis and Policies. London: Routledge. 
Laws, E., Scott, N. and Parfitt, N. (2002). Synergies in Destination Image Management: A Case Study and Conceptualisation, International Journal of Tourism Research, 4(1): 39-55.

Liu, C., Marchewka, J.T., Lu, J. and Yu, C.S. (2005). Beyond Concern: A Privacy-Trust Behavioral Intention Model of Electronic Commerce, Information \& Management, 42: 289-304.

Lorcu, F. (2015). Örneklerle Veri analizi - SPSS Uygulamalı. Ankara: Detay Yayıncılık.

McIntyre, G., Hetherington, A. and Inskeep, E. (1993). Sustainable Tourism Development: Guide for Local Planners. Madrid: UNWTO.

Morgan, N., Pritchard, A. and Piggott, R. (2002). New Zealand, 100\% Pure. The Creation of a Powerful Niche Destination Brand, Brand Management, 9(4/5): 335-354.

Murphy, J. (1998). What is branding?, (Editor) Hart, S., and Murphy, J.: In Brands: The New Wealth Creator. New York: New York University Press.

Murphy, P., Pritchard, M. P. and Smith, B. (2000). The Distinction Product and its Impact on Traveler Perceptions, Tourism Management, 21: 43-52.

Odabaşı, Y. ve Oyman, M. (2006). Pazarlama İletişimi Yönetimi (6.Baskı). İstanbul: Mediacat.

Oliveira, E. and Panyik, E. (2015). Content, Context and Co-Creation: Digital Challenges in Destination Branding with References to Portugal as a Tourist Destination, Journal of Vacation Marketing, 21(1): 53-74.

Ooi, C. S. (2004). Poetics and Politics of Destination Branding: Denmark, Scandinavian Journal of Hospitality and Tourism, 4(2): 107-128.

Özdemir, G. (2007). Destinasyon Yönetimi ve Pazarlama Temelleri: İzmir İçin Bir Destinasyon Model Önerisi, Yayınlanmamış Doktora Tezi, Dokuz Eylül Üniversitesi, İzmir.

Özdemir, Ş. ve Karaca, Y. (2009). Kent Markası ve Marka İmajının Ölçümü: Afyonkarahisar Kenti İmajı Üzerine Bir Araştırma, Afyon Kocatepe Üniversitesi İktisadi ve İdari Bilimler Fakültesi Dergisi, 11(2): 113-134.

Pamukçu, H. (2017). Konaklama İşletmelerinde Helâl Turizm Standardizasyonu Önerisi, Yayınlanmamış Doktora Tezi, Sakarya Üniversitesi, Sakarya.

Papadopoulos, N. and Heslop, L. (2002). Country Equity and Country Branding: Problems and Prospects, Brand Management, 9(4/5): 294-314.

Pritchard, A. and Morgan, N. J. (2001). Culture, Identity and Tourism Representation: Marketing Cymru of Wales?, Tourism Management, 22: 167-179.

Şahin, E. (2015). Bir Destinasyon Unsuru Olarak Yerel Gastronominin Marka Şehir Pazarlamasında Etkileri: Gaziantep Örneği, Yayınlanmamış Yüksek Lisans Tezi, Gaziantep Üniversitesi, Gaziantep.

Şanlıurfa Büyükşehir Belediyesi. (2018). Şanlıurfa 2. Ulusal Kitap Fuarı. [Çevirimiçi] https://www.sanliurfa.bel.tr/etkinlik/127/sanliurfa--2-ulusal-kitap-fuari [Erişim tarihi: 26.06.2019].

Şenesen, Ü. (2006). İstatistik: Sayıların Arkasını Anlamak. İstanbul: Literatür Yayınları.

Şimşek, M. ve Gürtuna, R. (2007). Toplam Kalite Yönetimi. İstanbul: Alfa Yayınları.

Tavşancıl, E. (2005). Tutumların Ölçülmesi ve SPSS ile Veri Analizi. (2. Baskı). Ankara: Nobel Yayınları. 
Toscano, M., Toscano, N., Ramsey, P. P., and Smidt, R. K. (2001). Instructor's Solutions Manual [for] Applied Statistics for Engineers and Scientists: Using Microsoft Excel and Minitab. New Jersey: Prentice Hall.

Ward S., Light L., and Goldstein J. (1999). What High-Tech Managers Need to Know About Brand, Harvard Business Review, July-August, 85-95.

Williams, P. W., Gill, A. M., and Chura, N. (2004). Branding Mountain Destinations: The Battle for "Peacefulness", Tourism review, 59(1): 6-15.

Yıldırım, A. ve Şimşek H. (2008). Sosyal Bilimlerde Nitel Araştırma Yöntemleri. Ankara: Seçkin Yayincilik.

Yücenur, G. N., Demirel, N. Ç., Ceylan, C., ve Demirel, T. (2011). Hizmet Değerinin Müşterilerin Davranışsal Niyetleri Üzerindeki Etkisinin Yapısal Eşitlik Modeli ile Ölçülmesi, Doğuş Üniversitesi Dergisi, 12(1): 156-168. 